\title{
Web Page Ranking using Web Mining Techniques: A comprehensive survey
}

This paper was downloaded from TechRxiv (https://www.techrxiv.org).

\section{LICENSE}

CC BY 4.0

SUBMISSION DATE / POSTED DATE

21-09-2021 / 23-09-2021

CITATION

Sharma, Prem Sagar; Yadav, Divakar (2021): Web Page Ranking using Web Mining Techniques: A comprehensive survey. TechRxiv. Preprint. https://doi.org/10.36227/techrxiv.16654330.v1

$\mathrm{DOI}$

10.36227/techrxiv.16654330.v1 


\title{
Web Page Ranking using Web Mining Techniques: A comprehensive survey
}

\author{
Prem Sagar Sharma ${ }^{1}$, Divakar Yadav²* \\ ${ }^{1}$ Uttarakhand Technical University, Dehradun (UK), India \\ ${ }^{2}$ National Institute of Technology, Hamirpur (HP), India \\ premsagar1987@ rediffmail.com, dsy99@rediffmail.com
}

ORCID ID: https://orcid.org/0000-0001-6051-479X

\begin{abstract}
Purpose: Due to the exponential growth of internet users and internet traffic, information seekers are highly dependent upon search engines to extract relevant information. Due to the accessibility of a large amount of textual, audio, video etc. contents, the responsibility of search engines has increased.

Design/methodology/approach: The search engine provides relevant information to internet users concerning to their query; based on content, link structure etc. However, it does not provide the guarantee of the correctness of the information. The performance of a search engine is highly dependent upon the ranking module. The performance of the ranking module is dependent upon the link structure of web pages, which analyse through Web structure mining (WSM) and their content, which analyses through Web content mining (WCM). Web mining plays an important role in computing the rank of web pages.

Findings: In this article, web mining types, techniques, tools, algorithms and their challenges are presented. Further, it provides a critical comprehensive survey for the researchers by presenting different features of web pages, which are important to check the quality of web pages.

Originality: In this work, authors presented different approaches/techniques, algorithms and evaluation approaches in previous researches and identified some critical issues in page ranking \& web mining, which provide future directions for the researchers, working in the area.
\end{abstract}

Keywords: World Wide Web, Information retrieval, Web page ranking, Search engine, Web mining.

\section{Introduction}

The size of web documents over the World Wide Web (WWW) has exponentially increased, due to increasing the dependency of users over the internet. An automatic system is required to fetch reliable information from such a huge collection of web documents because this task is very difficult to analyze manually. Search engine[1][2][3] is an information retrieval tool for the Web like Google, Yahoo, Bing etc. The summary of various search engines is shown in table-1. Still, these search systems are sometimes not able to provide guarantee about reliable and accurate information but still, these systems provide better results than performing the task manually by experts. Many times these tools do not provide precise information because the IR system[4] returns information to internet users based on some specific retrieval criteria. For instance, it fetches web documents based on subject/title as given. To fetch huge web documents related to a specific domain is very easy and common. Therefore, to find reliable/matched web documents for user/client queries, search engines provide a ranking system. Generally, a ranking mechanism creates the rank of web pages based on either keywords/reliability or links/popularity.

Hyperlinked Structure[5] has been developed in 1989 to share information among researchers in Switzerland. Later it becomes a platform of WWW development guided by the WWW association at MIT (Massachusetts Institute of Technology) in Cambridge. The recent growth of WWW has changed the computer science \& engineering as well as the people's lifestyles and economics of various countries.

The WWW is increasing exponentially (shown fig-1(a)) since its onset. 10 to 106 terabytes of traffic has increased in a month between 1995 \& 2000. The total web traffic between the years $2005 \& 2010$ increased from 1 to 7 Exabytes. Now in 2020 internet traffic is increasing approximate 5.3 Exabyte per day. According to Cisco, $82 \%$ of video-internet traffic of all web traffic will be in 2021. In 2016, $73 \%$ of video traffic[6] of all internets was present (shown fig-1(b)). People not only view large amounts of video, but they also use high bandwidth due to viewing good quality videos.

All types of web content (like video, Netflix, webcam etc.) is generating demand. Now growing live videos is an important part of the internet. These video offerings from various sources like live Facebook, Twitter's broadcast, live YouTube, live sports etc. is expected to increase approximately $13 \%$ of traffic (shown fig-1(c)) of total video web traffic by 2021[6]. WWW is an important and widely used tool to provide reliable 
information to internet user. It provides an important and easy mechanism for information (Like static text, images, dynamic \& interactive services such as audio/video conferences etc.) sharing. It provides the facility to view various types of information including magazines, library resources in different sectors, current $\&$ business news. Now the web is an important source of all kinds of information.

But searching for information on the web is a difficult job for an information seeker. Web-based information retrieval systems called search engines [7], though have made things easy for information seekers but do not provide guarantees about the correctness of the information. Many times the information is not precise. It is a program that searches for the documents for specified queries and returns the list of documents where the query keywords were found.

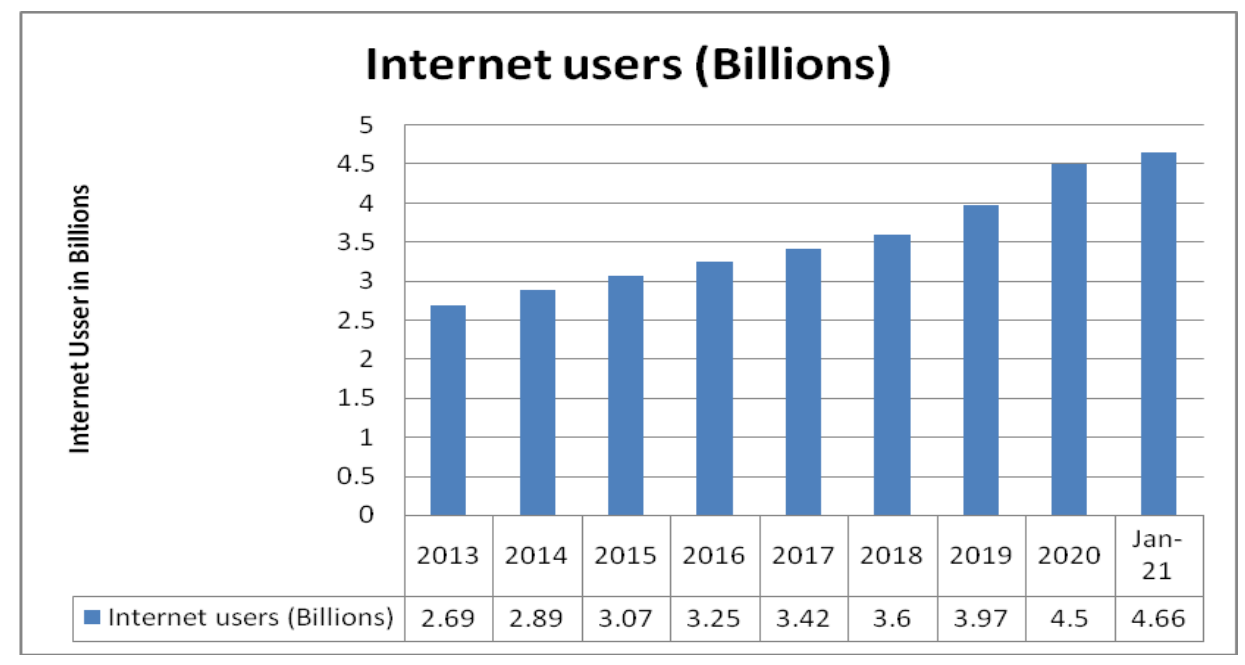

Figure 1 (a). The exponential growth in terms of actual total internet Users [6]

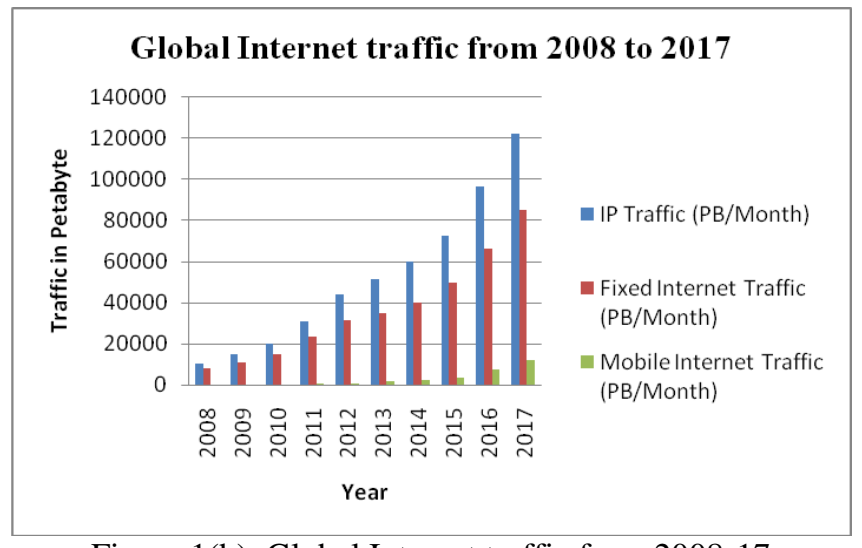

Figure 1(b). Global Internet traffic from 2008-17

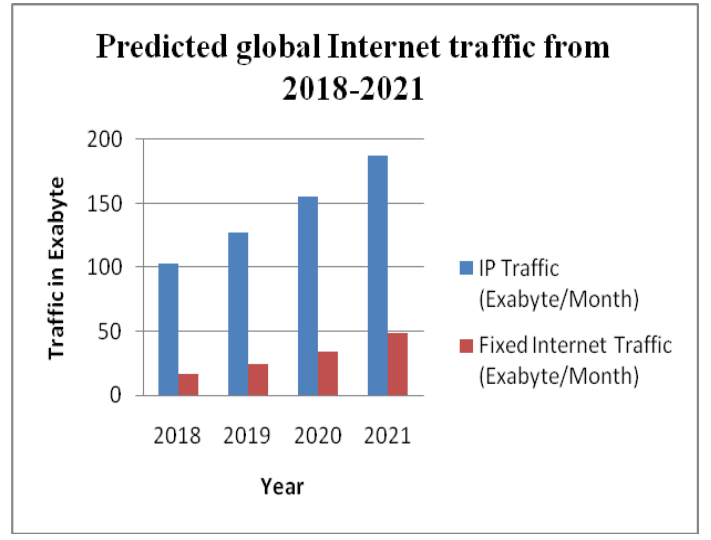

Figure 1(c). Predicted Global Internet traffic from 2018-21

It is important to understand that the term popularity is normally the result of link analysis and not user feedback. A web search engine (shown in figure-2) typically consists of a ranking system that measures the importance of Web Pages [8][9]. One can fetch content-based information from web documents using the hybrid approach [10]. The traffic of search engines is affected[11] by the following factors: Size of the web, loading speed (Page Redirect condition, Size of code) [12], Web security condition, SEO Crawling Factor (Title, heading, Meta Description of web page, Content, URL), User behaviour [8][13]. [14] presents a web page rank mechanism that is query dependent. This approach was much better and effective but it took more time to rank. In [15], the authors present a ranking mechanism based on link attributes but it was not able to check the content quality of the web page. Some content-based ranking approaches are presented in [16][17][18]. The main issue in content mining is that it was increasingly perceived latency, addressed this issue in [19] by an additional component said the proxy server.

Search Engines follow the following steps to process user queries:

a. Take user query and based on its keywords make a precise query to process. 
b. Analysis and Fetch data from web repository corresponding user request.

c. Ranked to all fetched web pages.

d. Return the list of URLs array of ranked web pages for the user request.

e. Get the updated user query of the user if any?

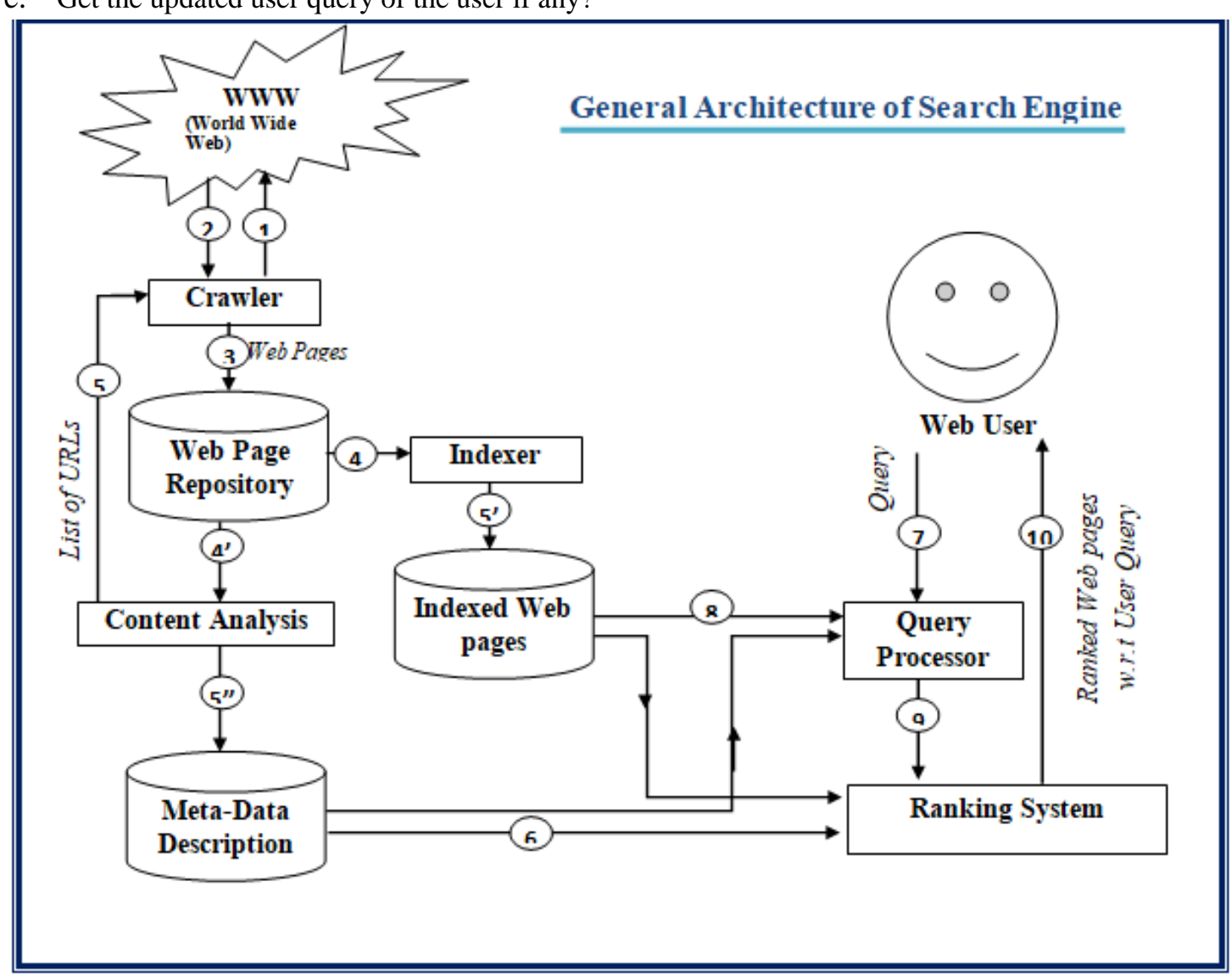

Figure 2. General Architecture of Search Engine

\section{Working Process of Search Engine:}

\section{frontend_search_enine(UserQuery)}

\{

result_QP = Quesry_processor(UserQuery, Indexed_Web_Repository, Meta_data);

ranked_web_pages = Ranking_system $($ result_QP, Meta_data);

\}

backend_search_engine (URL_List)

\{

WebPageRepository = Crawler $\left(U R L \_L i s t\right)$;

indexed_web_page_Repository = indexer (webPageRepository);

new_list_of_URLs = contentAnalysis(webPageRepository);

Meta_data = contentAnalysis(webPageRepository);

\}

Update_URL_List(URL_List, new_list_of_URLs);

\section{QueryProcessor(UserQuery, Indexed_Web_Repository, Meta_data)}

$$
\{
$$

Query_Token= Tokenizing (UserQuery); // Tokenize user query as user input query

Parse_query $=$ Parsing $($ Query_Token $)$;

// user may use special operators in query, which are need to be remove

Stqk = stemming (Remove_Stop_keyword(Parse_query, thesaurus));

// remove stop keywords \& do stemming

Precise_user_query $=$ Query_expansion $(\operatorname{Stqk})$; 
// to search reliable information need to be convert a user query into technical query

list_of_webpage $=$ Query_term_weighting(UserQuery, Indexed_Web_Repository,Meta_data)

return list_of_webpage;

\}

Table 1. History of various search engines [20]

\begin{tabular}{|c|c|c|}
\hline Search Engine & Year & Description \\
\hline Gerard Salton & $1960 s-1990 s$ & 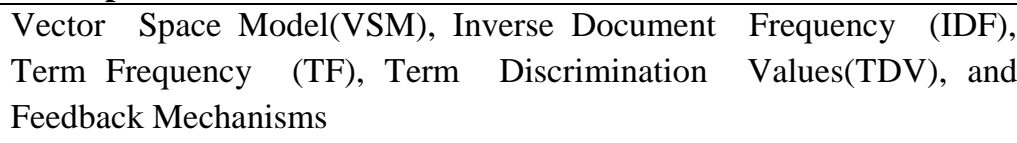 \\
\hline $\begin{array}{l}\text { Archie and } \\
\text { Veronica }\end{array}$ & 1991-1992 & $\begin{array}{l}\text { 'Archie' work for FTP sites \& 'Veronica' work for Gopherspace. } \\
\text { Gopherspace describes the aggregate of whole the information (like } \\
\text { document file, papers, abstracts and other types of files) on the various } \\
\text { Gopher servers in the world. }\end{array}$ \\
\hline $\begin{array}{l}\text { The First Web } \\
\text { Directory }\end{array}$ & 1993-1994 & $\begin{array}{l}\text { ALIweb (Archie Like Indexing) was created in October } 1993 \text { due to an } \\
\text { automated indexing problem. The first time it was creating a directory } \\
\text { for the web. It (directory) stores URLs and their description. }\end{array}$ \\
\hline Search Directories & 1994-1995 & $\begin{array}{l}\text { It was the first browser-based web directory. It is also doing help to the } \\
\text { user to coordinate directories. 'Yahoo' becomes more popular, which } \\
\text { provide an interface to make easy interaction for the user. }\end{array}$ \\
\hline Yahoo & 1995 & $\begin{array}{l}\text { Yahoo! Search Engine was developed in } 1995 \text {. It is written in PHP. } \\
\text { Originally, crawling and data storage was not done by Yahoo!. It was } \\
\text { the first popular web search engine. }\end{array}$ \\
\hline The Big-Guns & 1995 & $\begin{array}{l}\text { If the "Yahoo" search engine fails to return a result then AltaVista } \\
\text { search results automatically. It works for natural language queries and } \\
\text { Boolean searches. AltaVista was big as well as fast also. }\end{array}$ \\
\hline Meta-Engines & 1995 & $\begin{array}{l}\text { Meta engines play important role in search engines. There is nothing } \\
\text { new but they work together to collect results from various search } \\
\text { engines. it was introduced in } 1995 \text { in Washington. }\end{array}$ \\
\hline Ask & 1996 & $\begin{array}{l}\text { Ask.com also called Ask Jeeves is focused on question answering, } \\
\text { mainly for e-business developed in } 1996 \text { by Garrett Gruener and David } \\
\text { Warthen in Berkeley, California. The main task of this search engine } \\
\text { was to rank links based on popularity. }\end{array}$ \\
\hline Google & 1997 & $\begin{array}{l}\text { Larry Page and Sergey Brin developed the Google engine in } 1996 . \\
\text { Nowadays, Google is one of the most reliable search engines. It works } \\
\text { based on Web Structure Mining. }\end{array}$ \\
\hline Bing & 2009 & $\begin{array}{l}\text { MSN web portal developed in } 2005 \text { for in house search, but renamed in } \\
2009 \text { by Bing web search engine owned \& launched by Microsoft. It is } \\
\text { also called Microsoft Bing. Initially it work for window live search and } \\
\text { was later also used in live search. It was developed in ASP.NET. }\end{array}$ \\
\hline
\end{tabular}

\section{WEB MINING}

Data mining is used to find out relevant patterns or knowledge from repositories (like databases, texts, images etc.), which should be valid, useful and understandable. Text mining becomes popular and reliable by increasing the popularity of text documents. Web mining [21][22][23] is used to fetch useful/relevant information and use this information to generate knowledge and personalize the information and learn about users. The hyperlink structure of web pages, the content of web pages are used to collect the relevant information. Data mining techniques (shown in figure-3) [23][24]-[26] are used to fetch and discover relevant information automatically from web pages and web services in web mining. Data mining services are discussed in [27] to extract something useful out of the Web. There are following steps are needed to perform for this purpose: 
- Resource finding: Extract the useful data/resources from either web documents, which are available online, or offline mode.

- Information selection and pre-processing: Apply the pre-processing (cleaning, normalization, feature extraction) on the specific information, which is automatically selected.

- Transformation: Pre-proceed data is transformed into valuable information by removing stop words to obtain necessary phrases in training mass.

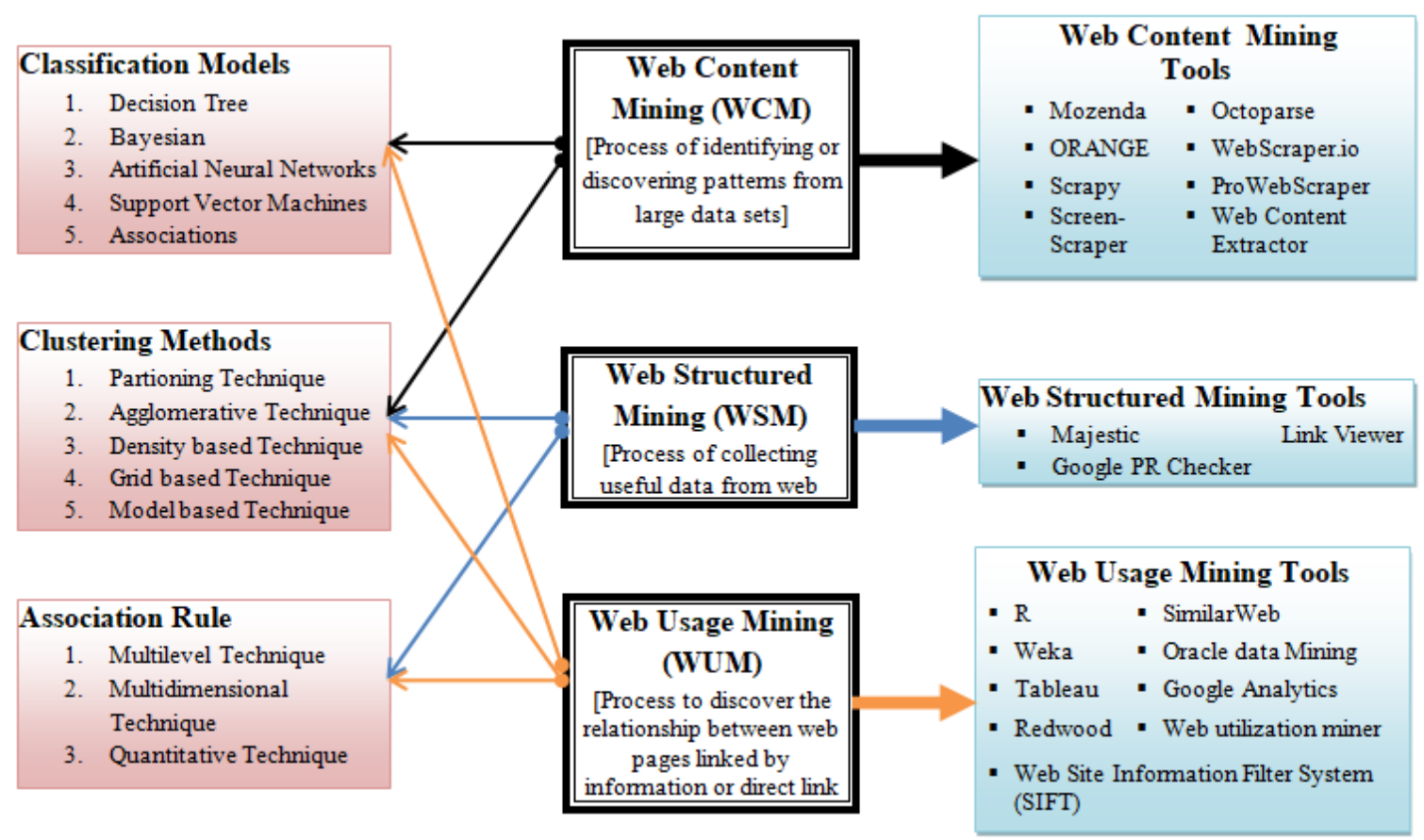

Figure 3. Summarization of web mining types, classification model and tools

- Generalization: It is used to fetch patterns from a website or across various websites by applying machine learning (ML) and other data mining techniques.

- Analysis: This phase analyses mined patterns by validation and interpretation. Pattern mining plays an important role in this phase. In knowledge generation on the web, human being plays an important role.

There are three basic information such as the previous pattern, shared content's degree and link structures in web mining discussed below:

\subsection{Web Usage Mining (WUM)}

Web and application servers are the main sources to collect web log data. Log files generate over the web whenever an internet user interacts with the web through search engines (shown in fig-4).

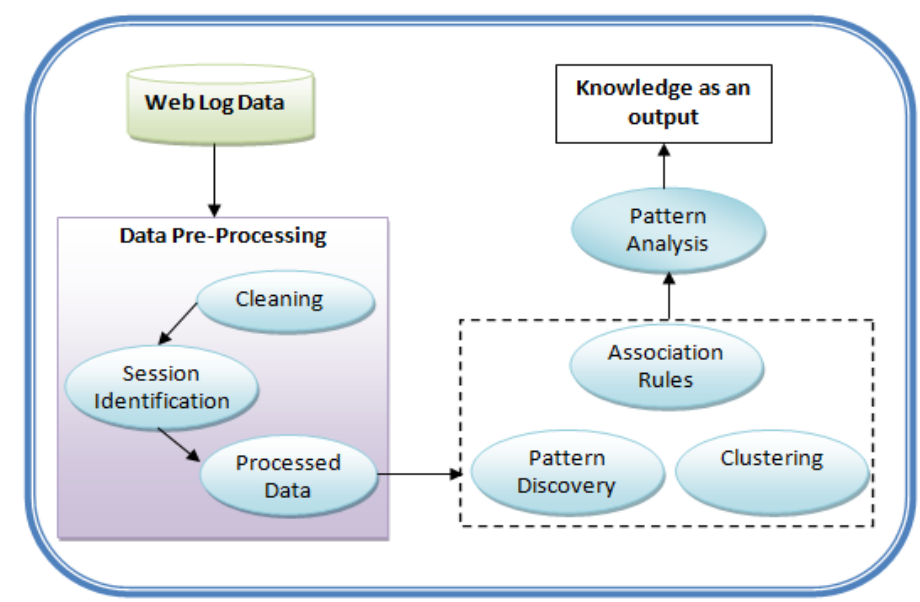

Figure 4. Architecture of Web Usages Mining (WUM) 
The following techniques [28] are used in web usage mining:

\subsubsection{Association Rules}

Association rules in WUM provide the relationship between web pages that frequently appear next to one another in user sessions [29][23].

Statement of association rules written as:

$$
\mathrm{A}=>\mathrm{B}
$$

Where, A, B are sets of items in a series of transactions.

For example, an association rule: Page $\mathrm{A}$, Page $\mathrm{B}=>$ Page $\mathrm{C}$ shows, if the user/client observe page $\mathrm{A}$, and $\mathrm{B}$ then page $\mathrm{C}$ will be observed in the same meeting.

\subsubsection{Classifications}

Classification is used to map a data item into predefined classes. The web usage mining process understands the existing data and behaviour of new instances. It identifies a particular class/category of a user. Classification techniques use Machine Learning (ML), Neural Network (NN) and statistical.

\subsubsection{Clustering}

Clustering techniques make sets of similar items from a large volumes of data by using distance functions which compute the similarity ratio between among items [29]. The contrast of the user/client and individual groups is a very important factor in such type of searching. There are two types of clustering, available in this area:

- User clustering

- Page clustering

User clustering is used to find those users which are having the same browser patterns and page clustering is used to find similar content's web pages.

\subsubsection{Sequential analysis}

Sequential analysis is that which found those patterns in which one set or set of pages are accessed one after another with a time sequence. For the prediction of future visitors this application works by advertising on users group. There are some techniques that are utilized for sequential analysis [28] as shown in table-2. A detailed description of various algorithms of WUM Techniques are given in table-2.

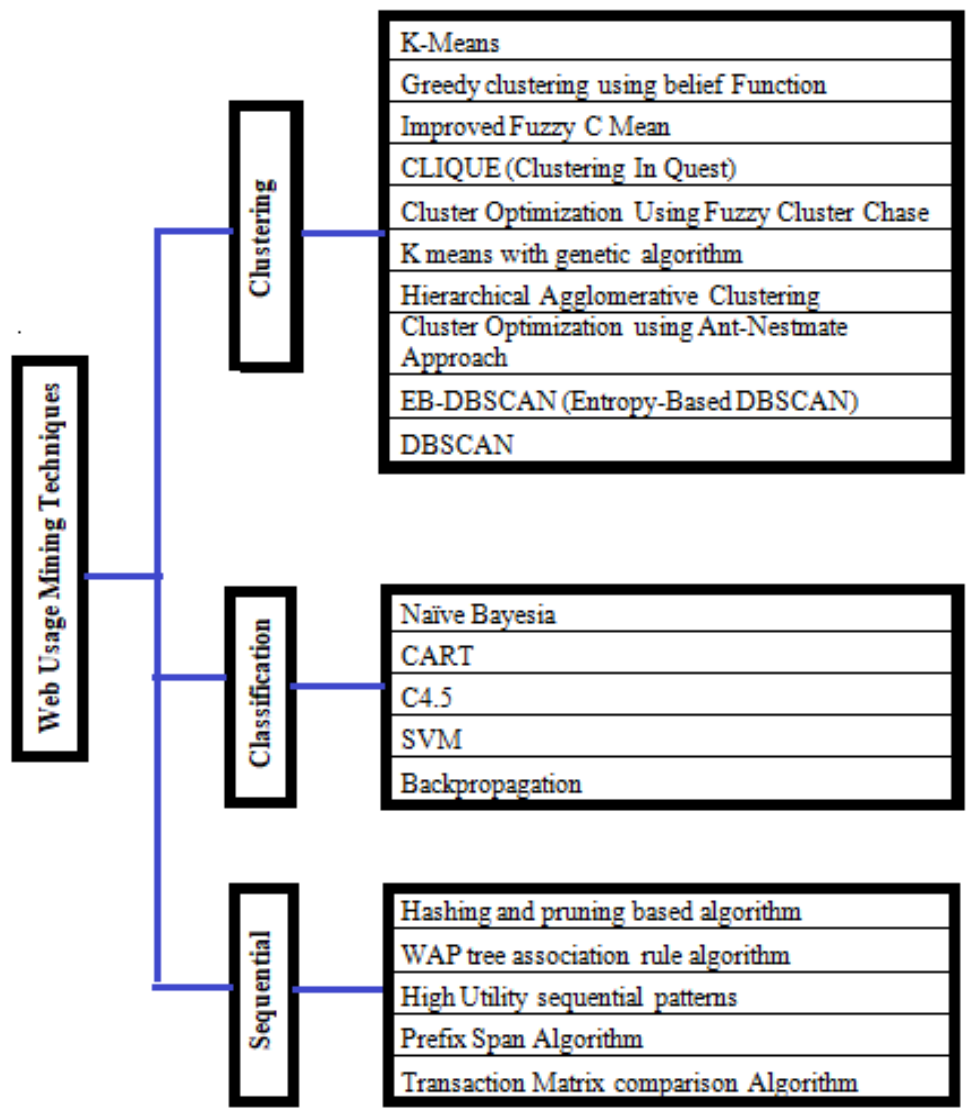

Figure 5. Algorithms used in Web Usage Mining's Techniques 
Table-2: Summary of Algorithms of WUM Techniques

\begin{tabular}{|c|c|c|}
\hline WUM Techniques & Algorithms & Description \\
\hline \multirow{10}{*}{ Clustering } & K-Means [31] & $\begin{array}{l}\text { It is an unsupervised algorithm used for data mining \& } \\
\text { pattern recognition, developed by J. B. MacQueen. The } \\
\text { aim of K-Means is to minimize the cluster performance } \\
\text { index. }\end{array}$ \\
\hline & $\begin{array}{l}\text { Greedy clustering using } \\
\text { belief Function [32][33] }\end{array}$ & $\begin{array}{l}\text { It is used to modelling evidence from expert opinions } \\
\text { or statistical information. }\end{array}$ \\
\hline & $\begin{array}{l}\text { Improved Fuzzy C Mean } \\
\text { [34] }\end{array}$ & $\begin{array}{l}\text { It is a basic approach, used for image segmentation in } \\
\text { which space divides into several clusters based on the } \\
\text { pixel value of an image. }\end{array}$ \\
\hline & $\begin{array}{l}\text { CLIQUE (Clustering In } \\
\text { Quest)[35] }\end{array}$ & $\begin{array}{l}\text { It is a subspace clustering algorithm that follows a } \\
\text { bottom-up approach used to create static grids. This } \\
\text { algorithm reduces the search space by using the Apriori } \\
\text { approach. }\end{array}$ \\
\hline & $\begin{array}{l}\text { Cluster Optimization } \\
\text { Using Fuzzy Cluster Chase } \\
{[36]}\end{array}$ & It is used to personalize web page clusters of end-users. \\
\hline & $\begin{array}{l}\text { K means with genetic } \\
\text { algorithm -Minimises } \\
\text { objective function [37] }\end{array}$ & $\begin{array}{l}\text { The GKA is the most preferable algorithm for } \\
\text { clustering to other evolutionary algorithms. }\end{array}$ \\
\hline & $\begin{array}{l}\text { Hierarchical } \\
\text { Agglomerative Clustering } \\
{[38]}\end{array}$ & $\begin{array}{l}\text { It is a data exploratory analysis technique used in } \\
\text { Hierarchical clustering. }\end{array}$ \\
\hline & $\begin{array}{l}\text { Cluster Optimization using } \\
\text { Ant-Nestmate Approach } \\
{[39]}\end{array}$ & $\begin{array}{l}\text { It is used to remove redundant data that may occur } \\
\text { during clustering. }\end{array}$ \\
\hline & $\begin{array}{l}\text { EB-DBSCAN (Entropy- } \\
\text { Based DBSCAN)[40] }\end{array}$ & It is used to identify the high-density regions/areas \\
\hline & DBSCAN [41] & It is used to make clusters of arbitrary shapes. \\
\hline \multirow{5}{*}{ Classification } & Naïve Bayesia [42] & $\begin{array}{l}\text { It is a work based on Bayes Theorem to find a class } \\
\text { with the highest probability from a predefined dataset } \\
\text { by counting combination on values }\end{array}$ \\
\hline & CART [43] & $\begin{array}{l}\text { It is a classification technique used to construct } \\
\text { decision trees for historical data. }\end{array}$ \\
\hline & C4.5 [44] & $\begin{array}{l}\text { It is a quick classification \& high precision algorithm. It } \\
\text { is used frequently for classification. }\end{array}$ \\
\hline & SVM [45] & $\begin{array}{l}\text { It is a classification algorithms that can be applied to } \\
\text { linear and non-linear datasets. }\end{array}$ \\
\hline & Backpropagation[46] & $\begin{array}{l}\text { It is used as a gradient descent method to minimize } \\
\text { error function in weight space. }\end{array}$ \\
\hline \multirow{4}{*}{ Sequential } & $\begin{array}{l}\text { Hashing and pruning based } \\
\text { algorithm [47] }\end{array}$ & $\begin{array}{l}\text { It is a famous association rule mining technique to } \\
\text { increase the performance of traditional Apriori } \\
\text { algorithms. }\end{array}$ \\
\hline & $\begin{array}{l}\text { WAP tree association rule } \\
\text { algorithm [48] }\end{array}$ & $\begin{array}{l}\text { WAP Tree is a way to store the patterns in an effective } \\
\text { manner by which these patterns are easily searchable. }\end{array}$ \\
\hline & $\begin{array}{l}\text { High Utility sequential } \\
\text { patterns [49] }\end{array}$ & $\begin{array}{l}\text { It is a data mining task that consists of a set of values } \\
\text { having importance in a quantitative transaction } \\
\text { database. }\end{array}$ \\
\hline & PrefixSpan Algorithm [50] & It fetches sequential patterns using the pattern growth \\
\hline
\end{tabular}




\begin{tabular}{|l|l|l|}
\hline & & method. It works well for small datasets. \\
\cline { 2 - 3 } & $\begin{array}{l}\text { Transaction Matrix } \\
\text { comparison Algorithm[51] }\end{array}$ & $\begin{array}{l}\text { It uses a boolean vector to discover frequent itemset. It } \\
\text { required less memory because itemset stored in bits. }\end{array}$ \\
\hline
\end{tabular}

\subsection{Web Content Mining (WCM)}

Web Content Mining (shown in figure-6) (WCM)[52]-[54][10]is used to fetch relevant \& Reliable information from web pages which may contain text documents, Hyperlinks, Structured data, audio \& Video. Nowadays web pages are increasing exponentially over www.

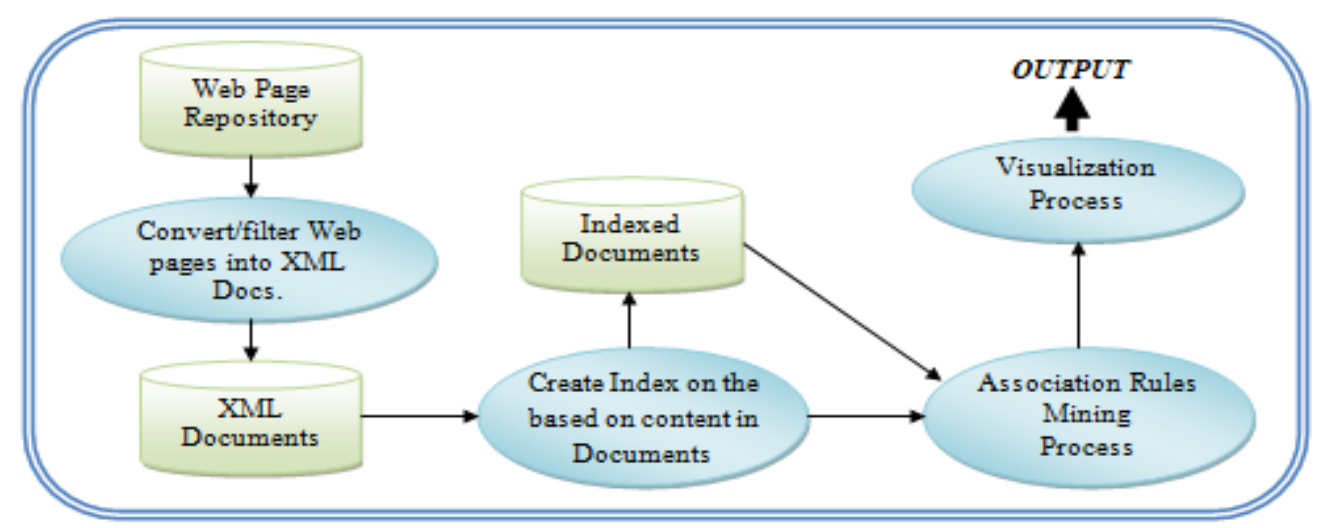

Figure. 6 Architecture of Web Content Mining (WCM)

Fetching relevant data related to user queries from a large collection of web pages is very difficult and very time-consuming. Web content mining has the following approaches [52] to extract user relevant information from different types of data like unstructured data, structure data, Semi-structured etc. There are various content mining algorithms[53] used by the above content mining techniques are shown in table-2:

Table 2: Summary of Content Mining Algorithms

\begin{tabular}{|l|l|}
\hline $\begin{array}{c}\text { Content Mining } \\
\text { Algorithms }\end{array}$ & \multicolumn{1}{c|}{ Description } \\
\hline Decision Trees & $\begin{array}{l}\text { It is a classification used by WCM \& WUM. It is also a structured approach that contains } \\
\text { root, branch and leaf nodes. The root is split into subtrees/branches and the leaf contains a } \\
\text { label of class }\end{array}$ \\
\hline Naïve Bayes & $\begin{array}{l}\text { It works based on Bayes Theorem. To find a class with the highest probability from a } \\
\text { predefined dataset by counting combinations of values. It is a very powerful and easy to an } \\
\text { understandable classifier }\end{array}$ \\
\hline $\begin{array}{l}\text { Support Vector } \\
\text { Machine }\end{array}$ & $\begin{array}{l}\text { It is a classification algorithms that can be applied to linear and non-linear datasets. The } \\
\text { separation of two classes (draw a decision boundary just as a line) depend on various } \\
\text { classification features. }\end{array}$ \\
\hline Neural network & $\begin{array}{l}\text { It works based on a backpropagation algorithm that contains a input layer, hidden layers } \\
\text { and an output layer. Each layer feeds to the next layer and the number of hidden layers are } \\
\text { arbitrary. }\end{array}$ \\
\hline
\end{tabular}

\subsection{Web Structure Mining (WSM)}

Web Structure Mining (architecture shown in fig-7) detects the structural summary of a web page and its linked web pages. It finds out link (forward/backward) structure inside a web page by structure mining [52][55]. It is used to classify and compare web documents and integrate number of different web documents.

Web structure mining (WSM) (shown in figure-7) follow the following steps:

- Apply link analysis on a web page repository to extract links (forward/backward) summary of web pages.

- Apply a link mining techniques in the summary to find out the weight or quality of the web pages. 


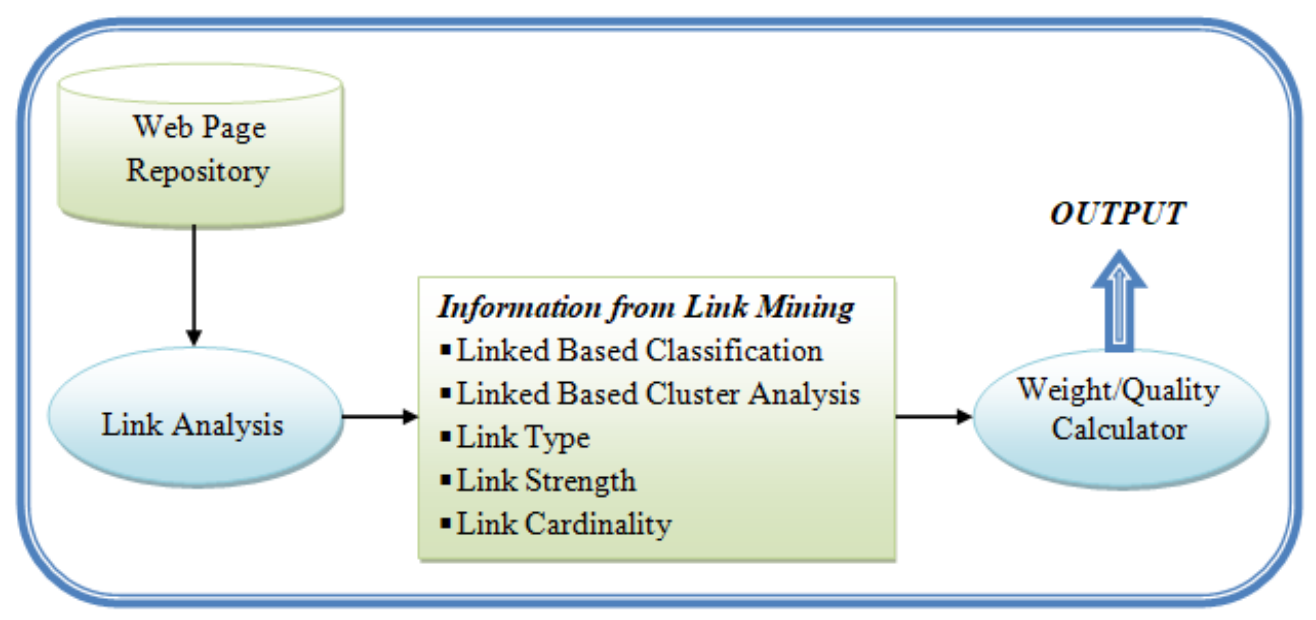

Figure 7. Architecture of Web Structure Mining (WSM)

Table-3: Summary of Structure Mining Algorithms

\begin{tabular}{|l|l|}
\hline Structure Mining Algorithm & \multicolumn{1}{c|}{ Description } \\
\hline Page Rank (PR) & Forward and backward links are used to compute the quality of a web page. \\
\hline Weighted Page Rank (WPR) & $\begin{array}{l}\text { Compute the weight of the pages based on their structure (links) and this } \\
\text { weight assigns to the page. Finally, generate rank based on weight. }\end{array}$ \\
\hline Eigen Rumor (ER) & It is the modified version of WPR by applying some other parameters. \\
\hline
\end{tabular}

\subsection{Challenges in Web Mining}

Web mining is faced with some technical and non-technical issues. Non-technical issues occur due to management, fund and resources (such as professional humans), Some technical issues are discussed below:

- Inappropriate data: Collected data should be reliable and in proper format to do successfully mining because many times data is incomplete and unavailable. It is very difficult to assure the accuracy of such a data.

- Complexity of web pages: The structure of a web page is not predefined. It is stored in a digital library (order of data is not defined) in its original format. So, mining of data is very complex.

- Dynamic Web: In dynamic web, data is frequently changed due to new updation. For example, sports data etc. Therefore, the complexity of mining is increased.

- Shortage of Mining Tools: Need to develop a mining tools because a very less number of appropriate and complete mining tools is available.

\subsection{Features of web page and importance of these features in a ranking system}

In this, we find out features of web pages and the importance of these features in the ranking system [11][56][57]-[60] of the search engines (shown in table-4). For each web page, there are fifteen features as given in the table, These features further divide into seven groups. All seven groups were finally categorized into three parts based on Web Mining types (WCM, WUM \& WSM)

Page: It has two characteristics one of them is Page rank (PR) score and the second one is the age (AGE) of web pages in an index of search engine.

Links: It is associated with links/URLs (forward/Backward Links) on the web Page.

Query and Text Similarity: It indicates similarity ratio between query keywords and contents of a web page[52]. It has main three features:

- Frequency of query keywords inside title

- Frequency of query keywords inside heading tags (H1, H2 .....H6) separately.

- Frequency of query keywords inside paragraph.

Head Tag: Head tag contains two features: title and meta data. Both are used based on keywords inside title and meta description. 
Body: it is associated with the density of keywords inside the body of a web page.

Content: associate with different features which are part of content analysis like headings, links/URLs etc.

Session Specific: in this count total number of clicks, count unique clicks and time duration for a session.

Table 4: Summary of parameters used in mining by Search Engine

\begin{tabular}{|c|c|c|c|}
\hline $\begin{array}{c}\text { Web } \\
\text { Mining } \\
\text { Techniques }\end{array}$ & $\begin{array}{l}\text { Components of } \\
\text { web page }\end{array}$ & Attributes & Description \\
\hline \multirow[b]{2}{*}{$*$} & \multirow[b]{2}{*}{ page } & Rank & Ranking value of web page \\
\hline & & Age & $\begin{array}{l}\text { Life of web page inside index of search } \\
\text { engine. }\end{array}$ \\
\hline \multirow{2}{*}{ 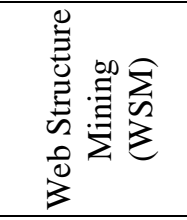 } & \multirow{2}{*}{ Links } & Forward Links & $\begin{array}{l}\text { Number of Links on that page point to other } \\
\text { web pages }\end{array}$ \\
\hline & & Backward Links & The number of web pages point to that page \\
\hline \multirow{10}{*}{ 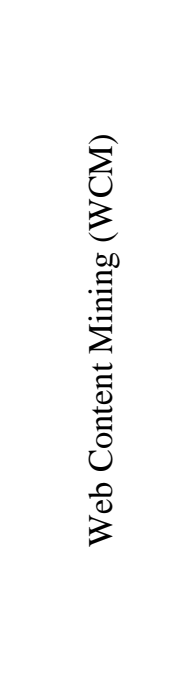 } & \multirow{3}{*}{$\begin{array}{l}\text { Query and Text } \\
\text { Similarty }\end{array}$} & Freq_QK_Title & Number of query keywords in $\langle$ title $\rangle\langle/$ title $\rangle$ \\
\hline & & Freq_QK_Heading & $\begin{array}{l}\text { Number of query keywords in heading }<\mathrm{h} 1> \\
. .<\mathrm{h} 6>\text { tags. }\end{array}$ \\
\hline & & Freq_QK_paragraph & $\begin{array}{l}\text { Number of query keywords in paragraph } \\
\langle\mathrm{p}\rangle\langle/ \mathrm{p}\rangle \text { tags. }\end{array}$ \\
\hline & \multirow[b]{2}{*}{ Head Tag } & Title & keywords written inside $\langle$ title $></$ title $>$ \\
\hline & & MetaData & $\begin{array}{l}\text { keywords in metadata key and description } \\
\text { tag }\end{array}$ \\
\hline & Body & Density & keyword density \\
\hline & \multirow{4}{*}{ Content } & Heading & * \\
\hline & & \multirow{3}{*}{ Links } & Heading Keywords \\
\hline & & & Images \\
\hline & & & Paragraph \\
\hline \multirow{3}{*}{ 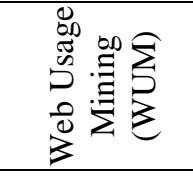 } & \multirow{3}{*}{ Session Specific } & Count clicks & Number of clicks during a session \\
\hline & & Count unique clicks & Number of unique click during a session \\
\hline & & Time duration for a session & Total time of a user session \\
\hline
\end{tabular}

\section{WEB PAGE RANKING SYSTEM}

Every day, millions of people's access search engines to retrieve information according to their needs, hence it becomes a common knowledge retrieval platform. The weight of the ranking in expert search for web documents is explained in [61]. The search engines have become the driver of internet users that move them towards the highly ranked web by using various web mining techniques[62]. In order to maintain the ranking of web pages, the main objective of the website is to attract internet users or clients, so that they can maintain the ranking on renewed search engines. Reinforcement learning for WPR (Web Pages Ranking) algorithms is explained in [63]. There are a several ways to improve the ranking of a web page on search engines, as SPAM farms are a very famous method to enhance a Web site's ranking. During Rank calculation of web pages, cognitive spammer framework (CSF) delete all spam web documents [64]. A framework Preference-based Universal Ranking Integration (PURI) [65] is designed by combining various ranking mechanisms. The internet is an important source to access information from the web. While almost all web pages contain a lot of noise in web like: advertisements, different types of banners, unreliable links etc. that affect the performance of content and structure based search engines, Question -Answering System, Web Summarization [10]. For instance, it 
fetches web documents based on subject/title as given. To fetch huge web documents related to a specific domain is very easy and common. Therefore, to find reliable/matched web documents for user/client queries, search engines provide a ranking system. The g-index based expert-ranking system in which mainly Rep-FS, Exp-PC and weighted Exp-PC techniques are used, explained in [66]. Ranking system utilize various web page ranking algorithms like page rank [15][67], weighted page rank [68], Eigenrumor [69], HITS [70], Weight Links Rank [18],distance ranking [71], tag rank [72],query dependent[14] to compute a rank of web page. It returns the order of web pages (order is done based on their rank). Table 5 shows the summary of web mining techniques and ranking algorithms for each mining technique.

Table-5: Summary of web mining Techniques based on various parameters

\begin{tabular}{|c|c|c|c|c|c|c|c|}
\hline $\begin{array}{l}\text { Web } \\
\text { Mining } \\
\text { Techniques }\end{array}$ & Data & Algorithms & Methodology & $\begin{array}{c}\text { List of } \\
\text { Input } \\
\text { Parameters }\end{array}$ & Complexity & Relevancy & Shortcomings \\
\hline \multirow{3}{*}{$\begin{array}{l}\text { Web } \\
\text { Structured } \\
\text { Mining } \\
\text { (WSM)[73] }\end{array}$} & \multirow[t]{3}{*}{$\begin{array}{l}\text { Hyperlinks, } \\
\text { Structure } \\
\text { of } \\
\text { Documents }\end{array}$} & $\begin{array}{l}\text { Page Rank } \\
\text { (PR) }\end{array}$ & $\begin{array}{l}\text { Forward \& } \\
\text { backward } \\
\text { Links are } \\
\text { used to } \\
\text { compute the } \\
\text { quality of the } \\
\text { web pages. }\end{array}$ & $\begin{array}{l}\text { Forward } \\
\text { and } \\
\text { backward } \\
\text { links }\end{array}$ & $\begin{array}{l}\text { PR take } \\
\text { O (log N) } \\
\text { Time to } \\
\text { compute } \\
\text { the rank }\end{array}$ & $\begin{array}{l}\text { Return } \\
\text { more } \\
\text { relevant } \\
\text { web pages }\end{array}$ & $\begin{array}{l}\text { It is not } \\
\text { considered } \\
\text { the content of } \\
\text { the web page. }\end{array}$ \\
\hline & & $\begin{array}{l}\text { Weighted } \\
\text { Page Rank } \\
\text { (WPR) }\end{array}$ & $\begin{array}{l}\text { Compute the } \\
\text { weight of the } \\
\text { pages based } \\
\text { on their } \\
\text { structure } \\
\text { (links) and } \\
\text { assign to the } \\
\text { page. Finally, } \\
\text { generate rank } \\
\text { based on } \\
\text { weight. }\end{array}$ & $\begin{array}{l}\text { Forward } \\
\text { and } \\
\text { backward } \\
\text { links }\end{array}$ & $\begin{array}{l}\text { The time } \\
\text { complexity } \\
\text { of WPR is } \\
\mathrm{O}(\log \mathrm{N})\end{array}$ & $\begin{array}{l}\text { It returns } \\
\text { more } \\
\text { relevant } \\
\text { web pages } \\
\text { as } \\
\text { compared } \\
\text { to the } \\
\text { page rank } \\
\text { algorithm }\end{array}$ & $\begin{array}{l}\text { It is not } \\
\text { considered } \\
\text { the content of } \\
\text { the web page. }\end{array}$ \\
\hline & & $\begin{array}{l}\text { Eigen Rumor } \\
\text { (ER) }\end{array}$ & $\begin{array}{l}\text { It is the } \\
\text { modified } \\
\text { version of } \\
\text { WPR by } \\
\text { applying } \\
\text { some other } \\
\text { parameters. }\end{array}$ & $\begin{array}{l}\text { Blogs, } \\
\text { Forward } \\
\text { and } \\
\text { backward } \\
\text { links }\end{array}$ & $\begin{array}{l}\text { The time } \\
\text { Complexity } \\
\text { of ER is } \\
\log N\end{array}$ & $\begin{array}{c}\text { It } \\
\text { provides } \\
\text { more } \\
\text { relevant } \\
\text { as } \\
\text { compare } \\
\text { to PR \& } \\
\text { WPR }\end{array}$ & $\begin{array}{l}\text { Rely on web } \\
\text { structure to } \\
\text { compute page } \\
\text { rank }\end{array}$ \\
\hline \multirow{3}{*}{$\begin{array}{c}\text { Web } \\
\text { Content } \\
\text { Mining } \\
\text { (WCM)[73] }\end{array}$} & \multirow[t]{3}{*}{$\begin{array}{l}\text { Text, } \\
\text { Image, } \\
\text { Audio, } \\
\text { Video, } \\
\text { Structure } \\
\text { Record }\end{array}$} & HITS & $\begin{array}{l}\text { Monitor and } \\
\text { consider } \\
\text { those web } \\
\text { pages which } \\
\text { are visited by } \\
\text { internet users } \\
\text { regularly }\end{array}$ & $\begin{array}{l}\text { History of } \\
\text { users' } \log \\
\text { files }\end{array}$ & $\begin{array}{c}\text { Time } \\
\text { complexity } \\
\text { is } \\
\mathrm{O}(\log \mathrm{N})\end{array}$ & $\begin{array}{l}\text { The } \\
\text { relevancy } \\
\text { of this } \\
\text { approach } \\
\text { is } \\
\text { moderate }\end{array}$ & $\begin{array}{l}\text { Due to only } \\
\text { rely on it is } \\
\text { not much } \\
\text { efficient }\end{array}$ \\
\hline & & $\begin{array}{c}\text { Weight } \\
\text { Links Rank } \\
\text { (WL Rank) }\end{array}$ & $\begin{array}{l}\text { It use the } \\
\text { position of } \\
\text { forward/ } \\
\text { backward } \\
\text { links to } \\
\text { compute the } \\
\text { rank of web } \\
\text { page }\end{array}$ & $\begin{array}{l}\text { Link } \\
\text { structure \& } \\
\text { Content }\end{array}$ & $*$ & $*$ & $\begin{array}{l}\text { It is not } \\
\text { reliable } \\
\text { because links } \\
\text { are not placed } \\
\text { at the proper } \\
\text { location// } \\
\text { position. }\end{array}$ \\
\hline & & $\begin{array}{c}\text { Distance } \\
\text { Ranking(DR) }\end{array}$ & $\begin{array}{l}\text { The } \\
\text { reinforcement }\end{array}$ & $\begin{array}{l}\text { After } \\
\text { crawling, it }\end{array}$ & $\begin{array}{c}\text { Time taken } \\
\text { by DR is }\end{array}$ & $*$ & $\begin{array}{l}\text { The } \\
\text { logarithmic }\end{array}$ \\
\hline
\end{tabular}




\begin{tabular}{|c|c|c|c|c|c|c|c|}
\hline & & & $\begin{array}{l}\text { learning } \\
\text { algorithm is } \\
\text { used by DR } \\
\text { to compute } \\
\text { the rank of } \\
\text { the web page. }\end{array}$ & $\begin{array}{l}\text { compute the } \\
\text { distance } \\
\text { between 2- } \\
\text { web pages. }\end{array}$ & $\mathrm{O}(\log \mathrm{N})$ & & $\begin{array}{l}\text { distance } \\
\text { between 2- } \\
\text { web pages is } \\
\text { not reliable. }\end{array}$ \\
\hline & & $\begin{array}{c}\text { Tag } \\
\text { Rank(TR) }\end{array}$ & $\begin{array}{lr}\text { Hub } & \& \\
\text { Authority } \\
\text { concept are } \\
\text { used } \\
\text { generate to } \\
\text { rank }\end{array}$ & $\begin{array}{l}\text { Forward, } \\
\text { backward } \\
\text { and tags on } \\
\text { web pages }\end{array}$ & $\begin{array}{l}\text { TR takes } \\
\text { O (log N) } \\
\text { time }\end{array}$ & $\begin{array}{l}\text { Relevancy } \\
\text { is } \\
\text { moderate }\end{array}$ & $\begin{array}{l}\text { It is less } \\
\text { efficient }\end{array}$ \\
\hline & & $\begin{array}{l}\text { Dirichlet } \\
\text { Rank }\end{array}$ & $\begin{array}{l}\text { It uses } \\
\text { attributes of } \\
\text { link like } \\
\text { position, } \\
\text { anchor text, } \\
\text { tag where } \\
\text { links exist, to } \\
\text { compute the } \\
\text { rank }\end{array}$ & $\begin{array}{l}\text { Position of } \\
\text { link, name } \\
\text { of tags in } \\
\text { which link } \\
\text { exist, } \\
\text { anchor text }\end{array}$ & $*$ & $*$ & $\begin{array}{l}\text { The relevancy } \\
\text { is not affected } \\
\text { by the } \\
\text { position of the } \\
\text { link }\end{array}$ \\
\hline \multirow{2}{*}{$\begin{array}{l}\text { Web Usage } \\
\text { Mining } \\
\text { (WUM)[73] }\end{array}$} & \multirow[t]{2}{*}{$\begin{array}{c}\text { Web } \\
\text { Server } \\
\text { Logs, App } \\
\text { Server } \\
\text { Logs, App } \\
\text { Level Logs }\end{array}$} & $\begin{array}{c}\text { Query } \\
\text { Dependent } \\
\text { Ranking }\end{array}$ & $\begin{array}{lr}\text { It } & \text { uses } \\
\text { similar } & \text { user } \\
\text { queries } & \text { to } \\
\text { compute } & \text { the } \\
\text { rank } & \end{array}$ & $\begin{array}{l}\text { Training } \\
\text { queries }\end{array}$ & $*$ & $\begin{array}{l}\text { Relevancy } \\
\text { is high. It } \\
\text { returns all } \\
\text { the same } \\
\text { web pages } \\
\text { to a same } \\
\text { user query }\end{array}$ & $\begin{array}{l}\text { There are } \\
\text { limited } \\
\text { numbers of } \\
\text { characteristics } \\
\text { to find the } \\
\text { similarity. }\end{array}$ \\
\hline & & SimRank & $\begin{array}{l}\text { Design a rank } \\
\text { model for the } \\
\text { same type of } \\
\text { user queries }\end{array}$ & $\begin{array}{l}\text { Training } \\
\text { queries }\end{array}$ & * & $\begin{array}{l}\text { Relevancy } \\
\text { is high. it } \\
\text { returns all } \\
\text { the same } \\
\text { web pages } \\
\text { to the } \\
\text { same user } \\
\text { query }\end{array}$ & $\begin{array}{l}\text { There are } \\
\text { limited } \\
\text { numbers of } \\
\text { characteristics } \\
\text { to find the } \\
\text { similarity. } \\
\text {. }\end{array}$ \\
\hline
\end{tabular}

\section{LITERATURE REVIEW}

Due to increasing the information for humans on the WWW, the responsibility of the internet also increased. It is very easy for us to collect the information from www using search engines. Search engines return a large number of web pages as information for a user query. It is very difficult for users to select reliable information among them. Therefore, in this section we will discuss research papers in which the author tries to improve search engine techniques that support to users to select reliable information.

In [74], authors give an approach to fetch experts attributes by using text mining from the web i.e. it is a recommended model to return a precise record. This research has shown the effectiveness of the proposed approach is box-office revenue prediction. In [75] the author proposed a prediction for movie revenue based on YouTube trailer reviews. It is mainly utilized in business intelligence as well as in decision making. In [76] the author developed a framework for Geographic Information Mining (GIM) framework. Microsoft discussion(MSD) forums used ExpertRank [77], a technique to find experts. This methodology used documentbased relevance as well as authority. It does not consider MSD features (like rating by the user which is a more reliable feature used to mine expert users). In [78] author identified user activities in the SO- forum and compared with their GitHub repositories, and feasible features of user (active in both platforms). In [79] author proposed user activity models for stackoverflow, Wenwo Forums \& SinaWeibo to classify real experts. In [80] the model uses some basic features to compute the user weight. In this model the question-answer ratio is used to generate user weight, still, it ignores the consistency of the user. Besides this, the quality of the tag was not considered. Although, it may lead to more reliable and accurate recommendation systems. The link-based expert finding techniques mainly used the structure of links instead of their contents. Link analysis used 
question-answer relationship[81], to find experts, citation networks [82] \& email communications[83]. For online users, in [84] the author presented an automatic expert finding model. In this model, the profile of user expertise was evaluated based on social network score and postconditions. The Z- Score, PageRank, In-degree \& HITS etc. algorithms were used to compute social network authority scores. A search engine to fetch biomedical information [58] return all the documents corresponding user query from MEDLINE based on word/concept indexes.

Several researchers have investigated various ranking approaches by using different methodologies that increase the efficiency of search engines to provide highly relevant web pages for a particular user query. Table 6 presents the summary of various research papers based on different attributes like methodologies, approaches, pros and cons etc.

Table 6 Summary of previous research on basis of various parameters

\begin{tabular}{|c|c|c|c|c|c|c|c|}
\hline$\underset{\dot{z}}{\dot{n}}$ & 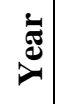 & Title & Journal & Author & $\begin{array}{l}\text { Methodology/ } \\
\text { Approach }\end{array}$ & Advantages & Limitations \\
\hline 1 & ડิ & $\begin{array}{l}\text { Using } \\
\text { Machine } \\
\text { Learning } \\
\text { for Web } \\
\text { Page } \\
\text { Classificati } \\
\text { on in } \\
\text { Search } \\
\text { Engine } \\
\text { Optimizati } \\
\text { on [85] }\end{array}$ & $\begin{array}{l}\text { Future } \\
\text { Internet } \\
2021,13,9\end{array}$ & $\begin{array}{c}\text { Goran } \\
\text { Matosevi, } \\
\text { Jasminka } \\
\text { Dobsa, Dunja } \\
\text { Mladeni }\end{array}$ & $\begin{array}{l}\text { Authors used machine } \\
\text { learning to classify } \\
\text { web pages in SEO. }\end{array}$ & $\begin{array}{l}\text { Methods used in } \\
\text { this research can } \\
\text { help in building } \\
\text { automated or semi- } \\
\text { automated } \\
\text { software for } \\
\text { supporting SEO } \\
\text { work. }\end{array}$ & $\begin{array}{l}\text { It is } \\
\text { language- } \\
\text { specific. }\end{array}$ \\
\hline 2 & 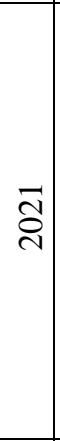 & $\begin{array}{l}\text { Learning } \\
\text { to Rank } \\
\text { for } \\
\text { Educationa } \\
1 \text { Search } \\
\text { Engines } \\
{[11]}\end{array}$ & $\begin{array}{l}\text { IEEE } \\
\text { Transactions }\end{array}$ & $\begin{array}{l}\text { Arif Usta, } \\
\text { Ismail Sengor } \\
\text { Altingovde, } \\
\text { Rifat Ozcan, } \\
\text { and Ozgur } \\
\text { Ulusoy }\end{array}$ & $\begin{array}{l}\text { Machine Learning } \\
\text { (ML) techniques. } \\
\text { It is also called } \\
\text { learning to } \\
\text { rank (LTR). }\end{array}$ & \begin{tabular}{|l|} 
It expose general \\
and user query \\
dependent \\
ranking models. \\
It used LTR to \\
trained, to increase \\
high reliability in \\
educational search. \\
It provides better \\
learning practice. \\
\end{tabular} & $\begin{array}{l}\text { It has } \\
\text { domain- } \\
\text { specific } \\
\text { features, and } \\
\text { increases the } \\
\text { perceived } \\
\text { latency due } \\
\text { to query } \\
\text { dependence. }\end{array}$ \\
\hline 3 & 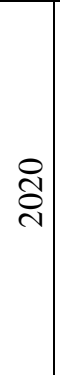 & $\begin{array}{l}\text { Big Data } \\
\text { Analytics } \\
\text { for Search } \\
\text { Engine } \\
\text { Optimizati } \\
\text { on [86] }\end{array}$ & $\begin{array}{l}\text { MDPI, Big } \\
\text { Data and } \\
\text { Cognitive } \\
\text { computing }\end{array}$ & $\begin{array}{l}\text { Ioannis C. } \\
\text { Drivas, } \\
\text { Damianos P. } \\
\text { Sakas, Georgios } \\
\text { A. } \\
\text { Giannakopoulos } \\
\text {, Daphne } \\
\text { Kyriaki- } \\
\text { Manessi }\end{array}$ & $\begin{array}{l}\text { Author used agent } \\
\text { based model, fuzzy } \\
\text { cognitive mapping and } \\
\text { big data analytics. }\end{array}$ & $\begin{array}{l}\text { It increases the } \\
\text { organic search } \\
\text { engine visits by } \\
\text { using multiple } \\
\text { SEO factors. }\end{array}$ & $\begin{array}{l}\text { This process } \\
\text { of search } \\
\text { engine } \\
\text { optimization } \\
\text { (SEO) could } \\
\text { be a cost } \\
\text { effective. }\end{array}$ \\
\hline 4 & ๙ิి & $\begin{array}{l}\text { Incrementa } \\
1 \\
\text { Refinemen } \\
t \text { of Page } \\
\text { Ranking of } \\
\text { Web } \\
\text { Pages[19] }\end{array}$ & $\begin{array}{l}\text { Int. J. Inf. } \\
\text { Retr. } \quad \text { Res., } \\
\text { vol. 11, no. 2 }\end{array}$ & $\begin{array}{l}\text { P. S. Sharma, } \\
\text { Divakar Yadav }\end{array}$ & $\begin{array}{l}\text { Author used frequency } \\
\text { of query keyword, } \\
\text { hyperlink on query } \\
\text { keywords and proxy } \\
\text { server approach. }\end{array}$ & $\begin{array}{l}\text { It improves } \\
\text { webpage ranking } \\
\text { and reduces } \\
\text { perceived latency. }\end{array}$ & $\begin{array}{l}\text { Authors } \\
\text { applied this } \\
\text { approach } \\
\text { only on web } \\
\text { data. }\end{array}$ \\
\hline 5 & $\frac{a}{2}$ & $\begin{array}{l}\text { Natural- } \\
\text { language- } \\
\text { based } \\
\text { intelligent } \\
\text { retrieval }\end{array}$ & $\begin{array}{l}\text { Computers } \\
\text { in Industry } \\
\text { (Elsevier) }\end{array}$ & $\begin{array}{c}\text { Songfei Wua, } \\
\text { Qiyu Shena, } \\
\text { Yichuan Denga, } \\
\text { Jack Chengc }\end{array}$ & $\begin{array}{c}\text { NLP (Natural } \\
\text { Language Processing). }\end{array}$ & $\begin{array}{l}\text { It reduce threshold } \\
\text { by using BIM } \\
\text { object database. }\end{array}$ & $\begin{array}{l}\text { It is domain } \\
\text { specific. } \\
\text { Used } \\
\text { ontology to } \\
\text { understand }\end{array}$ \\
\hline
\end{tabular}




\begin{tabular}{|c|c|c|c|c|c|c|c|}
\hline & & $\begin{array}{l}\text { engine for } \\
\text { BIM } \\
\text { object } \\
\text { database } \\
{[87]}\end{array}$ & & & & & semantic. \\
\hline 6 & $\frac{a}{\delta}$ & $\begin{array}{l}\text { Jail-Phish: } \\
\text { An } \\
\text { improved } \\
\text { search } \\
\text { engine } \\
\text { based } \\
\text { phishing } \\
\text { detection } \\
\text { system } \\
\text { [88] }\end{array}$ & $\begin{array}{l}\text { Computers } \\
\text { in Industry } \\
\text { (Elsevier) }\end{array}$ & $\begin{array}{c}\text { Routhu } \\
\text { Srinivasa Rao, } \\
\text { Alwyn Roshan } \\
\text { Pais }\end{array}$ & $\begin{array}{l}\text { Author used heuristic } \\
\text { technique to fetch } \\
\text { similarity based } \\
\text { features to identify the } \\
\text { phishing websites. }\end{array}$ & $\begin{array}{l}\text { It is used to } \\
\text { identify the } \\
\text { malicious users } \\
\text { and also to detect } \\
\text { phishing sites. } \\
\text { It also works on } \\
\text { free hosted } \\
\text { websites. }\end{array}$ & $\begin{array}{l}\text { It is used as } \\
\text { third party } \\
\text { based } \\
\text { features to } \\
\text { identify } \\
\text { phishing } \\
\text { sites on free } \\
\text { hosted webs. }\end{array}$ \\
\hline 7 & & $\begin{array}{l}\text { Forecastin } \\
\mathrm{g} \text { tourist } \\
\text { arrivals } \\
\text { with } \\
\text { machine } \\
\text { learning } \\
\text { and } \\
\text { internet } \\
\text { search } \\
\text { index [89] }\end{array}$ & $\begin{array}{c}\text { Tourism } \\
\text { Management } \\
\text { (Elsevier) }\end{array}$ & $\begin{array}{l}\text { Shaolong } \\
\text { Suna, Yunjie } \\
\text { Weia, Kwok- } \\
\text { Leung Tsuic, } \\
\text { Shouyang } \\
\text { Wanga }\end{array}$ & $\begin{array}{c}\text { Author used } \\
\text { Machine Learning } \\
\text { (ML) } \\
\text { and indexes of search } \\
\text { engines. }\end{array}$ & $\begin{array}{l}\text { It increase } \\
\text { forecasting } \\
\text { accuracy and } \\
\text { robustness. }\end{array}$ & $\begin{array}{l}\text { It is tested on } \\
1 \text { - test case. } \\
\text { It works on } \\
\text { keyword } \\
\text { selection. }\end{array}$ \\
\hline 8 & $\frac{a}{\delta}$ & $\begin{array}{l}\text { An } \\
\text { investigati } \\
\text { on of } \\
\text { biases in } \\
\text { web } \\
\text { search } \\
\text { engine } \\
\text { query } \\
\text { suggestion } \\
\text { s[90] }\end{array}$ & $\begin{array}{l}\text { Online } \\
\text { Information } \\
\text { Review, Vol. } \\
44 \text { No. 2, } \\
2020, \text { pp. } \\
365-381 \\
\text { C Emerald } \\
\text { Publishing } \\
\text { Limited }\end{array}$ & $\begin{array}{l}\text { Malte } \\
\text { Bonart,Anastasi } \\
\text { ia } \\
\text { Samokhina,Ger } \\
\text { not Heisenberg } \\
\text { and Philipp } \\
\text { Schaer }\end{array}$ & $\begin{array}{c}\text { Author designed a } \\
\text { framework that } \\
\text { automatically analyzes } \\
\text { query suggestions for } \\
\text { the web user. }\end{array}$ & $\begin{array}{l}\text { It is capable of } \\
\text { automatically } \\
\text { collecting and } \\
\text { analyzing query } \\
\text { suggestions for a } \\
\text { large repository of } \\
\text { search keywords. }\end{array}$ & $\begin{array}{l}\text { It is topics } \\
\text { derived. } \\
\text { It is for the } \\
\text { politician } \\
\text { domain only. }\end{array}$ \\
\hline 9 & $\frac{\infty}{\stackrel{\nu}{\sigma}}$ & $\begin{array}{c}\text { Improving } \\
\text { search } \\
\text { engine } \\
\text { optimizati } \\
\text { on (SEO) } \\
\text { by using } \\
\text { hybrid } \\
\text { modified } \\
\text { MCDMmo } \\
\text { dels [8] }\end{array}$ & $\begin{array}{c}\text { Artificial } \\
\text { Intelligence } \\
\text { Review } \\
\text { https://doi.or } \\
\text { g/10.1007/s1 } \\
0462-018- \\
\text { 9644-0 } \\
\text { (Springer) }\end{array}$ & $\begin{array}{l}\text { Hung-Jia Tsuei, } \\
\text { Wei-Ho Tsai, } \\
\text { Fu-Te Pan, } \\
\text { Gwo-Hshiung } \\
\text { Tzeng }\end{array}$ & $\begin{array}{c}\text { Multi-Criteria } \\
\text { Decision-Making } \\
\text { (MCDM, also known } \\
\text { as Multi-Criteria } \\
\text { Decision Analysis, } \\
\text { MCDA). }\end{array}$ & $\begin{array}{l}\text { Improving and } \\
\text { evaluating search } \\
\text { engine ranking. }\end{array}$ & $\begin{array}{l}\text { Need to } \\
\text { improve on } \\
\text { low-value } \\
\text { websites. }\end{array}$ \\
\hline 10 & $\frac{1}{\delta}$ & $\begin{array}{l}\text { IBRI- } \\
\text { CASONT } \\
\text { O: } \\
\text { Ontology- } \\
\text { based } \\
\text { semantic } \\
\text { search } \\
\text { engine } \\
{[91]}\end{array}$ & $\begin{array}{l}\text { Egyptian } \\
\text { Informatics } \\
\text { Journal } \\
\text { (Elsevier) }\end{array}$ & $\begin{array}{c}\text { Awny Sayed, } \\
\text { Amal Al } \\
\text { Muqrishi }\end{array}$ & $\begin{array}{l}\text { Resource Description } \\
\text { Framework (RDF) } \\
\text { data } \\
\text { \& Ontological graph. }\end{array}$ & $\begin{array}{l}\text { It supports Arabic } \\
\text { and English } \\
\text { language. It use } \\
\text { keyword-based } \\
\text { search and a } \\
\text { semantics-based } \\
\text { search. }\end{array}$ & $\begin{array}{l}\text { It is Domain } \\
\text { Specific. } \\
\text { Indexing } \\
\text { mechanism } \\
\text { is not } \\
\text { working for } \\
\text { large data } \\
\text { sets. }\end{array}$ \\
\hline 11 & $\frac{\pi}{0}$ & $\begin{array}{l}\text { Death } \\
\text { Prediction } \\
\text { and }\end{array}$ & $\begin{array}{l}\text { ICACCS - } \\
2015, \\
\text { Coimbatore, }\end{array}$ & $\begin{array}{l}\text { Hesham Abdo, } \\
\text { Ahmed Aqlan, } \\
\text { Et. al. }\end{array}$ & $\begin{array}{lr}\text { Author } & \text { used } \\
\text { regression } & \text { and } \\
\text { Network } & \text { based }\end{array}$ & $\begin{array}{l}\text { It used the latest } \\
\text { AI methodologies } \\
\text { to improve page }\end{array}$ & $\begin{array}{l}\text { Need to find } \\
\text { suitable AI } \\
\text { techniques to }\end{array}$ \\
\hline
\end{tabular}




\begin{tabular}{|c|c|c|c|c|c|c|c|}
\hline & & $\begin{array}{l}\text { Analysis } \\
\text { Using Web } \\
\text { Mining } \\
\text { Technique } \\
\text { s [92] }\end{array}$ & \begin{tabular}{|l|} 
INDIA- 978- \\
$1-5090-4559-$ \\
$4 / 17 / \$ 31-$ \\
EEE
\end{tabular} & & $\begin{array}{ll}\text { methodology } & \text { to } \\
\text { compute the rank of } \\
\text { the webpages. }\end{array}$ & rank algorithms. & $\begin{array}{l}\text { improve the } \\
\text { prediction } \\
\text { approach. }\end{array}$ \\
\hline 12 & $\frac{\bar{\sigma}}{\mathrm{D}}$ & $\begin{array}{l}\text { Design of } \\
\text { a } \\
\text { Framewor } \\
\text { k for } \\
\text { Knowledg } \\
\text { e Based } \\
\text { Web Page } \\
\text { Ranking } \\
{[93]}\end{array}$ & $\begin{array}{l}\text { Int. J. Eng. } \\
\text { Technol }\end{array}$ & $\begin{array}{l}\text { P. Sharma, S. } \\
\text { A.K, and P. } \\
\text { Garg }\end{array}$ & $\begin{array}{l}\text { Author used frequency } \\
\text { of query keywords and } \\
\text { proxy server approach. }\end{array}$ & $\begin{array}{l}\text { It reduce perceived } \\
\text { latency. }\end{array}$ & $\begin{array}{l}\text { Synchronizat } \\
\text { ion problem } \\
\text { between } \\
\text { proxy and } \\
\text { search } \\
\text { engines. }\end{array}$ \\
\hline 13 & 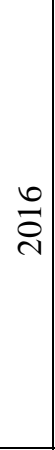 & $\begin{array}{l}\text { New query } \\
\text { suggestion } \\
\text { framework } \\
\text { and } \\
\text { algorithms } \\
: \text { A case } \\
\text { study for } \\
\text { an } \\
\text { educationa } \\
1 \text { search } \\
\text { engine[94] }\end{array}$ & $\begin{array}{l}\text { Information } \\
\text { Processing } \\
\text { and } \\
\text { Management } \\
\text { (Elsevier) }\end{array}$ & $\begin{array}{c}\text { Bahattin } \\
\text { Vidinli , Rifat } \\
\text { Ozcan }\end{array}$ & $\begin{array}{l}\text { Authors designed a } \\
\text { framework query } \\
\text { suggestion. }\end{array}$ & $\begin{array}{l}\text { It can be reduced } \\
\text { (simplified) to a } \\
\text { problem of query } \\
\text { compression. }\end{array}$ & $\begin{array}{l}\text { Need to be } \\
\text { including } \\
\text { spell checker } \\
\text { to increase } \\
\text { suggestion } \\
\text { accuracy and } \\
\text { needs to } \\
\text { integrate } \\
\text { content also. }\end{array}$ \\
\hline 14 & $\frac{n}{\grave{n}}$ & $\begin{array}{l}\text { Search- } \\
\text { based QoS } \\
\text { ranking } \\
\text { prediction } \\
\text { for web } \\
\text { services in } \\
\text { cloud } \\
\text { environme } \\
\text { nts[95] }\end{array}$ & $\begin{array}{l}\text { Future } \\
\text { Generation } \\
\text { Computer } \\
\text { Systems } \\
\text { (Elsevier) }\end{array}$ & $\begin{array}{l}\text { Mao, } \\
\text { Chengying } \\
\text { Chen, Jifu } \\
\text { Towey, Dave } \\
\text { Chen, Jinfu } \\
\text { Xie, Xiaoyuan }\end{array}$ & $\begin{array}{l}\text { Author explore } \\
\text { similarity } \\
\text { measurement method } \\
\text { for two ranked } \\
\text { sequences. } \\
\text { It predicts QoS } \\
\text { ranking. }\end{array}$ & $\begin{array}{l}\text { The QoS } \\
\text { information was } \\
\text { used for ranking } \\
\text { prediction. }\end{array}$ & $\begin{array}{l}\text { It does not } \\
\text { use social } \\
\text { relationships } \\
\text { in the cloud } \\
\text { platform } \\
\text { which is } \\
\text { important. }\end{array}$ \\
\hline 15 & $\stackrel{ \pm}{\stackrel{\Xi}{\Xi}}$ & $\begin{array}{l}\text { Effective } \\
\text { ranking } \\
\text { and search } \\
\text { techniques } \\
\text { for Web } \\
\text { resources } \\
\text { considerin } \\
\text { g semantic } \\
\text { relationshi } \\
\text { ps [96] }\end{array}$ & $\begin{array}{l}\text { Information } \\
\text { Processing } \\
\text { and } \\
\text { Management } \\
\text { (Elsevier) }\end{array}$ & $\begin{array}{l}\text { Lee, Jihyun } \\
\text { Min, Jun Ki } \\
\text { Oh, Alice } \\
\text { Chung, Chin } \\
\text { Wan }\end{array}$ & $\begin{array}{l}\text { Use ontology to } \\
\text { compute weight for } \\
\text { the semantic } \\
\text { relationship. }\end{array}$ & $\begin{array}{l}\text { It increased the } \\
\text { power of the query } \\
\text { keyword for } \\
\text { semantic } \\
\text { relationship. } \\
\text { It reduced the } \\
\text { search space and } \\
\text { increased the } \\
\text { accuracy. }\end{array}$ & $\begin{array}{l}\text { It used } \\
\text { ontology. }\end{array}$ \\
\hline 16 & $\frac{m}{\grave{n}}$ & $\begin{array}{l}\text { A hybrid } \\
\text { approach } \\
\text { for } \\
\text { extracting } \\
\text { informativ } \\
\text { e content } \\
\text { from web } \\
\text { pages[10] }\end{array}$ & $\begin{array}{l}\text { Information } \\
\text { Processing } \\
\text { and } \\
\text { Management } \\
49(2013) \\
928-944 \\
\text { Contents } \\
\text { (Elsevier) }\end{array}$ & $\begin{array}{c}\text { Erdinç Uzun, } \\
\text { Hayri Volkan } \\
\text { Agun, Tarık } \\
\text { Yerlikaya }\end{array}$ & $\begin{array}{l}\text { It uses Decision Tree } \\
\text { Learning to fetch } \\
\text { informative contents } \\
\text { and make rules. } \\
\text { Extract reliable } \\
\text { information by using } \\
\text { these rules. }\end{array}$ & $\begin{array}{l}\text { It is very faster } \\
\text { after making rules } \\
\text { and provides high } \\
\text { accuracy in results. }\end{array}$ & $\begin{array}{l}\text { It takes more } \\
\text { time for rules } \\
\text { creation the } \\
\text { first time. }\end{array}$ \\
\hline 17 & $\stackrel{m}{\stackrel{n}{2}}$ & $\begin{array}{l}\text { Topic- } \\
\text { Driven } \\
\text { SocialRan } \\
\text { k: } \\
\text { Personaliz } \\
\text { ed search }\end{array}$ & $\begin{array}{l}\text { Knowledge- } \\
\text { Based } \\
\text { Systems } 54 \\
(2013) 230- \\
242 \text { Contents }\end{array}$ & $\begin{array}{l}\text { Young An Kim } \\
\text {, Gun Woo Park }\end{array}$ & $\begin{array}{l}\text { Focus on identifying } \\
\text { similar users who have } \\
\text { high credibility and } \\
\text { sharing their search } \\
\text { experiences. }\end{array}$ & $\begin{array}{l}\text { It is very useful to } \\
\text { find more relevant } \\
\text { search results by } \\
\text { implicit help of } \\
\text { familiar, credible }\end{array}$ & $\begin{array}{l}\text { It is tested on } \\
\text { a small } \\
\text { dataset. }\end{array}$ \\
\hline
\end{tabular}




\begin{tabular}{|c|c|c|c|c|c|c|c|}
\hline & & $\begin{array}{l}\text { result } \\
\text { ranking by } \\
\text { identifying } \\
\text { similar, } \\
\text { credible } \\
\text { users in a } \\
\text { social } \\
\text { network } \\
{[97]}\end{array}$ & (Elsevier) & & & users. & \\
\hline 18 & $\frac{\sim}{\infty}$ & $\begin{array}{l}\text { Mining the } \\
\text { real-time } \\
\text { web: A } \\
\text { novel } \\
\text { approach } \\
\text { to product } \\
\text { recommen } \\
\text { dation[98] }\end{array}$ & $\begin{array}{l}\text { Knowledge- } \\
\text { Based } \\
\text { Systems } 29 \\
\text { (2012) 3-11 } \\
\text { (Elsevier) }\end{array}$ & $\begin{array}{c}\text { Garcia Esparza, } \\
\text { Sandra } \\
\text { O'Mahony, } \\
\text { Michael P. } \\
\text { Smyth, Barry }\end{array}$ & $\begin{array}{l}\text { It uses a collaborative- } \\
\text { filtering based } \\
\text { approach. }\end{array}$ & $\begin{array}{l}\text { It is used for } \\
\text { micro-blogging } \\
\text { messages. }\end{array}$ & $\begin{array}{l}\text { It is not used } \\
\text { by other } \\
\text { domains like } \\
\text { Twitter. }\end{array}$ \\
\hline 19 & $\bar{\sigma}$ & $\begin{array}{l}\text { A music } \\
\text { informatio } \\
n \text { system } \\
\text { automatica } \\
\text { lly } \\
\text { generated } \\
\text { via Web } \\
\text { content } \\
\text { mining } \\
\text { techniques } \\
\text { Markus } \\
{[99]}\end{array}$ & $\begin{array}{l}\text { Information } \\
\text { Processing } \\
\text { and } \\
\text { Management } \\
47(2011) \\
426-439 \\
\text { (Elsevier) }\end{array}$ & $\begin{array}{l}\text { Markus Schedl, } \\
\text { Gerhard } \\
\text { Widmer, Peter } \\
\text { Knees, Tim } \\
\text { Pohle }\end{array}$ & $\begin{array}{l}\text { It uses web content } \\
\text { mining techniques. }\end{array}$ & $\begin{array}{l}\text { It provides web- } \\
\text { based access to a } \\
\text { large collection of } \\
\text { music artists. } \\
\text { It is automated } \\
\text { music information } \\
\text { system. }\end{array}$ & $\begin{array}{l}\text { It is domain } \\
\text { specific (for } \\
\text { music only). }\end{array}$ \\
\hline 20 & $\bar{\Xi}$ & $\begin{array}{l}\text { Snoogle: A } \\
\text { Search } \\
\text { Engine for } \\
\text { Pervasive } \\
\text { Environme } \\
\text { nts[100] }\end{array}$ & $\begin{array}{l}\text { IEEE } \\
\text { Transactions } \\
\text { On Parallel } \\
\text { and } \\
\text { Distributed } \\
\text { Systems }\end{array}$ & $\begin{array}{l}\text { Haodong Wang, } \\
\text { Chiu C. Tan, } \\
\text { and Qun Li } \\
\text { Abstract- } \\
\text { Embedding }\end{array}$ & $\begin{array}{l}\text { It uses sensor } \\
\text { networks, } \\
\text { And communication } \\
\text { overhead reduced by } \\
\text { Bloom filters. }\end{array}$ & $\begin{array}{l}\text { In this, user can } \\
\text { search a mobile } \\
\text { object (s) that fit in } \\
\text { detail. }\end{array}$ & $\begin{array}{l}\text { This system } \\
\text { is not able to } \\
\text { find a } \\
\text { moving } \\
\text { object in } \\
\text { real-time. }\end{array}$ \\
\hline
\end{tabular}

4.1 Some observations have been seen in available literature reviews, which are discussed below:

Observation 1: Mostly search engines return relevant web pages to users for their queries. Relevancy of web page depends upon in-link/ out-link (i.e. web structure mining) and popularity of web page.

Many times, the most relevant web pages may be less important for user queries. Important web pages, according to user queries may be missing out from the result. So, new techniques are required to develop that may consider user queries as an additional parameter to find the relevant web pages for those queries.

Observation 2: Due to increasing the size of the web, search engines delay returning a list of web pages as output to users. The delay between user query submissions and to get output is called perceived latency. Therefore, a prefetching mechanism needs to be developed to reduce the response time.

Observation 3: Even with the introduction of a prefetching mechanism that aims to reduce the user perceived latency, unsuccessful predictions made to prefetch the pages may result in information overkill. Thus, a mechanism is required that could actually make credible predictions for only those pages that are more relevant, i.e. make correct predictions to minimize the problem of information overkill.

Observation 4: Due to increasing WWW and internet users, it is very difficult to fetch the information, which is looked at, by a specific group of users. For example, in an organization all employees may request the same type of information. Therefore, it require approaches that personalize the content of web pages with respect to the user's group.

\section{CONCLUSION AND FUTURE SCOPE}


Three categories of ranking algorithms are mainly discussed. The first category of algorithm, which is based on content of web pages is known as content-based page ranking. The second category of algorithm, which uses link structure of world wide web is known as web structure-based page ranking algorithms and the third category used hybrid of the first and second categories. Ranking systems highly rely upon web mining techniques but some issues need to be addressed in web mining due to improper data, shortage of mining tools and some other challenges in classification and clustering techniques.

There are several limitations of the existing ranking systems, which define the challenge and new research paths for researchers. The observations about existing research work will help the researcher to select the specific area where further research may be initiated.

There are some challenges related to web page ranking such as:

- Web structure-based page ranking algorithms may ignore web pages, which have less page ranking score but have good content for a user query. Content-based page ranking algorithms take more time to find page rank because of content mining at query time.

- The size of WWW is very large so content mining is a very time-consuming process to check the quality of web pages. There is a need to reduce the time taken by search engines to return the results.

\section{References}

[1] C. Ziakis, M. Vlachopoulou, T. Kyrkoudis, and M. Karagkiozidou, "Important factors for improving Google search rank," Futur. Internet, vol. 11, no. 2, 2019, doi: 10.3390/fi11020032.

[2] C. Fu, C. Peng, X. Y. Liu, L. T. Yang, J. Yang, and L. Han, "Search engine: The social relationship driving power of Internet of Things," Futur. Gener. Comput. Syst., vol. 92, pp. 972-986, 2019, doi: 10.1016/j.future.2018.01.037.

[3] D. Qiao, J. Zhang, Q. Wei, and G. Chen, "Finding competitive keywords from query logs to enhance search engine advertising," Inf. Manag., vol. 54, no. 4, pp. 531-543, 2017, doi: 10.1016/j.im.2016.11.003.

[4] Z. Hadjilambrou, M. Kleanthous, G. Antoniou, A. Portero, and Y. Sazeides, "Comprehensive Characterization of an Open Source Document Search Engine," ACM Trans. Archit. Code Optim., vol. 16, no. 2, 2019, doi: 10.1145/3320346.

[5] K. Mohan, “A Survey on Web Structure Mining,” Int. J. Adv. Comput. Res., vol. 1, no. 1, pp. 715-720, 2017.

[6] "CISCO: Global - 2021 Forecast Highlights.” https://www.cisco.com/c/dam/m/en_us/solutions/serviceprovider/vni-forecast-highlights/pdf/Global_2021_Forecast_Highlights.pdf.

[7] N. Höchstötter and D. Lewandowski, "What users see - Structures in search engine results pages," Inf. Sci. (Ny)., vol. 179, no. 12, pp. 1796-1812, 2009, doi: 10.1016/j.ins.2009.01.028.

[8] H. J. Tsuei, W. H. Tsai, F. Te Pan, and G. H. Tzeng, "Improving search engine optimization (SEO) by using hybrid modified MCDM models," Artif. Intell. Rev., vol. 53, no. 1, 2020, doi: 10.1007/s10462018-9644-0.

[9] B. J. Jansen and A. Spink, "How are we searching the World Wide Web? A comparison of nine search engine transaction logs," Inf. Process. Manag., vol. 42, no. 1 SPEC. ISS, pp. 248-263, 2006, doi: 10.1016/j.ipm.2004.10.007.

[10] E. Uzun, H. V. Agun, and T. Yerlikaya, "A hybrid approach for extracting informative content from web pages,” Inf. Process. Manag., vol. 49, no. 4, pp. 928-944, 2013, doi: 10.1016/j.ipm.2013.02.005.

[11] A. Usta, I. S. Altingovde, R. Ozcan, and O. Ulusoy, "Learning to Rank for Educational Search Engines," IEEE Trans. Learn. Technol., vol. 0050, no. c, pp. 1-14, 2021, doi: 10.1109/TLT.2021.3075196.

[12] O. Dan and B. D. Davison, "Measuring and predicting search engine users' satisfaction," ACM Comput. Surv., vol. 49, no. 1, 2016, doi: 10.1145/2893486.

[13] C. J. Luh, S. A. Yang, and T. L. D. Huang, "Estimating Google's search engine ranking function from a search engine optimization perspective," Online Inf. Rev., vol. 40, no. 2, pp. 239-255, 2016, doi: 10.1108/OIR-04-2015-0112.

[14] L. W. Lee, J. Y. Jiang, C. Der Wu, and S. J. Lee, "A query-dependent ranking approach for search engines," 2nd Int. Work. Comput. Sci. Eng. WCSE 2009, vol. 1, pp. 259-263, 2009, doi: 10.1109/WCSE.2009.666.

[15] R. Baeza-Yates and E. Davis, "Web Page Ranking using Link Attributes Categories and Subject Descriptors," Proc. 13th Int. World Wide Web Conf. Altern. track Pap. posters, pp. 328-329, 2004.

[16] G. Poonkuzhali, R. Kishore Kumar, P. Sudhakar, G. V. Uma, and K. Sarukesi, "Relevance ranking and evaluation of search results through web content mining," Lect. Notes Eng. Comput. Sci., vol. 2195, pp. 456-460, 2012. 
[17] R. K. Roul, S. R. Asthana, and G. Kumar, "Spam web page detection using combined content and link features," Int. J. Data Mining, Model. Manag., vol. 8, no. 3, pp. 209-222, 2016, doi: 10.1504/IJDMMM.2016.079063.

[18] P. Sharma, D. Tyagi, and P. Bhadana, "Weighted Page Content Rank for Ordering Web Search Result," Int. J. Eng. Sci. Technol., vol. 2, no. 12, pp. 7301-7310, 2010.

[19] P. S. Sharma and D. Yadav, "Incremental Refinement of Page Ranking of Web Pages," Int. J. Inf. Retr. Res., vol. 10, no. 3, pp. 57-73, 2020, doi: 10.4018/ijirr.2020070104.

[20] T. Seymour, D. Frantsvog, and S. Kumar, "History Of Search Engines," Int. J. Manag. Inf. Syst., vol. 15, no. 4, p. 47, 2011, doi: 10.19030/ijmis.v15i4.5799.

[21] D. Bollegala, Y. Matsuo, and M. Ishizuka, "A web search engine-based approach to measure semantic similarity between words," IEEE Trans. Knowl. Data Eng., vol. 23, no. 7, pp. 977-990, 2011, doi: 10.1109/TKDE.2010.172.

[22] A. Hogan, A. Harth, J. Umbrich, S. Kinsella, A. Polleres, and S. Decker, "Searching and browsing Linked Data with SWSE: The Semantic Web Search Engine,” J. Web Semant., vol. 9, no. 4, pp. 365401, 2011, doi: 10.1016/j.websem.2011.06.004.

[23] M. Jawad and H. Mughal, "Data Mining: Web Data Mining Techniques, Tools and Algorithms : An Overview," Int. J. Adv. Comput. Sci. Appl., vol. 9, no. 6, pp. 208-215, 2018.

[24] A. B. Can and N. Baykal, "MedicoPort: A medical search engine for all," Comput. Methods Programs Biomed., vol. 86, no. 1, pp. 73-86, 2007, doi: 10.1016/j.cmpb.2007.01.007.

[25] A. Anagnostopoulos, A. Z. Broder, and D. Carmel, "Sampling search-engine results," World Wide Web, vol. 9, no. 4, pp. 397-429, 2006, doi: 10.1007/s11280-006-0222-z.

[26] J. Bar-Ilan, M. Mat-Hassan, and M. Levene, "Methods for comparing rankings of search engine results," Comput. Networks, vol. 50, no. 10, pp. 1448-1463, 2006, doi: 10.1016/j.comnet.2005.10.020.

[27] M. Zorrilla and D. García-Saiz, "A service oriented architecture to provide data mining services for nonexpert data miners," Decis. Support Syst., vol. 55, no. 1, pp. 399-411, 2013, doi: 10.1016/j.dss.2012.05.045.

[28] P. Suthar and P. B. Oza, "A Survey on Web Usage Mining Techniques," Int. J. Comput. Sci. Inf. Technol., vol. 2, no. 10, pp. 3824-3829, 2015.

[29] M. Kumari and S. Soni, "A Review of classification in Web Usage Mining using K- Nearest Neighbour," Adv. Comput. Sci. Technol., vol. 10, no. 5, pp. 1405-1416, 2017.

[30] C. Vyas, "Evaluating state tourism websites using Search Engine Optimization tools," Tour. Manag., vol. 73, no. January, pp. 64-70, 2019, doi: 10.1016/j.tourman.2019.01.019.

[31] Y. Li and H. Wu, "A Clustering Method Based on K-Means Algorithm," Phys. Procedia, vol. 25, pp. 1104-1109, 2012, doi: 10.1016/j.phpro.2012.03.206.

[32] L. C. Principle, "Methods for building belief functions," pp. 1-67, 2011.

[33] A. Bakhthemmat and M. Izadi, "Communities Detection for Advertising by Futuristic Greedy Method with Clustering Approach,” Big Data, vol. 9, no. 1, pp. 22-40, 2021, doi: 10.1089/big.2020.0133.

[34] H. Rustum, H. Hadi, and A. AbdulZahraa, "Improved Fuzzy C-Mean Algorithm for Image Segmentation,” Int. J. Adv. Res. Artif. Intell., vol. 5, no. 6, 2016, doi: 10.14569/ijarai.2016.050602.

[35] J. Yadav and D. Kumar, "Subspace Clustering using CLIQUE : An Exploratory Study," Int. J. Adv. Res. Comput. Eng. Technol., vol. 3, no. 2, pp. 372-378, 2014.

[36] N. M. Varghese and J. John, "Cluster optimization for enhanced web usage mining using fuzzy logic," Proc. 2012 World Congr. Inf. Commun. Technol. WICT 2012, pp. 948-952, 2012, doi: 10.1109/WICT.2012.6409211.

[37] K. Krishna and M. N. Murty, "Genetic K-means algorithm,” IEEE Trans. Syst. Man, Cybern. Part B Cybern., vol. 29, no. 3, pp. 433-439, 1999, doi: 10.1109/3477.764879.

[38] P. Contreras and F. Murtagh, "Hierarchical clustering," Handb. Clust. Anal., no. February, pp. 103-124, 2015, doi: 10.1201/b19706.

[39] A. Alphy and S. Prabakaran, "Cluster optimization for improved web usage mining using ant nestmate approach," Int. Conf. Recent Trends Inf. Technol. ICRTIT 2011, pp. 1271-1276, 2011, doi: 10.1109/ICRTIT.2011.5972369.

[40] T. Wang, C. Ren, Y. Luo, and J. Tian, "NS-DBSCAN: A density-based clustering algorithm in network space,” ISPRS Int. J. Geo-Information, vol. 8, no. 5, 2019, doi: 10.3390/ijgi8050218.

[41] M. Daszykowski and B. Walczak, "Density-Based Clustering Methods," Compr. Chemom., vol. 2, pp. 635-654, 2009, doi: 10.1016/B978-044452701-1.00067-3.

[42] D. Berrar, "Bayes' theorem and naive bayes classifier," Encycl. Bioinforma. Comput. Biol. ABC Bioinforma., vol. 1-3, no. January 2018, pp. 403-412, 2018, doi: 10.1016/B978-0-12-809633-8.204731.

[43] D. Steinberg, "CART : Classification and Regression Trees," no. January 2009, 2015.

[44] I. I. Sinam and A. Lawan, "An improved C4.5 model classification algorithm based on Taylor's series," 
Jordanian J. Comput. Inf. Technol., vol. 5, no. 1, pp. 34-42, 2019, doi: 10.5455/jjcit.71-1546551963.

[45] M. Awad and R. Khanna, "Efficient learning machines: Theories, concepts, and applications for engineers and system designers," Effic. Learn. Mach. Theor. Concepts, Appl. Eng. Syst. Des., no. January, pp. 1-248, 2015, doi: 10.1007/978-1-4302-5990-9.

[46] I. Jung and G. Wang, "Pattern Classification of Back-Propagation Algorithm Using Exclusive Connecting Network," World Acad. Sci. Eng. Technol., vol. 36, no. February, pp. 189-193, 2007.

[47] H. Najadat, S. Amani, and O. Ghadeer, "A new perfect hashing and pruning algorithm for mining association rule," Bus. Transform. through Innov. Knowl. Manag. An Acad. Perspect. - Proc. 14th Int. Bus. Inf. Manag. Assoc. Conf. IBIMA 2010, vol. 4, no. January, pp. 2524-2531, 2010, doi: $10.5171 / 2011.6512178$.

[48] F. Zhan, X. Zhu, L. Zhang, X. Wang, L. Wang, and C. Liu, "Summary of Association Rules," IOP Conf. Ser. Earth Environ. Sci., vol. 252, no. 3, 2019, doi: 10.1088/1755-1315/252/3/032219.

[49] W. Jentner and D. A. Keim, High-Utility Pattern Mining, vol. 51, no. May. Springer International Publishing, 2019.

[50] P. Saraf, R. R Sedamkar, and S. Rathi, "PrefixSpan Algorithm for Finding Sequential Pattern with Various Constraints,” Int. J. Appl. Inf. Syst., vol. 9, no. 3, pp. 37-41, 2015, doi: 10.5120/ijais15-451380.

[51] Y. Yuan and T. Huang, "for Mining Association Rules," pp. 370-379, 2005.

[52] F. Johnson, "Web Content Mining Techniques: A Survey," Int. J. Comput. Appl., vol. 47, no. 11, pp. 44-50, 2012.

[53] R. Malarvizhi and K. Saraswathi, "Web Content Mining Techniques Tools \& Algorithms - A Comprehensive Study," Web Content Min. Tech. Tools Algorithms - A Compr. Study, vol. 4, no. 8, pp. 2940-2945, 2013, [Online]. Available: http://www.ijcttjournal.org.

[54] A. kumar, “A Study on Web Content Mining," Int. J. Eng. Comput. Sci., vol. 6, no. 1, pp. 2015-2018, 2017, doi: 10.18535/ijecs/v6i1.29.

[55] C. Hahnel, F. Goldhammer, U. Kröhne, and J. Naumann, "The role of reading skills in the evaluation of online information gathered from search engine environments," Comput. Human Behav., vol. 78, pp. 223-234, 2018, doi: 10.1016/j.chb.2017.10.004.

[56] D. Sirdeshmukh, N. B. Ahmad, M. S. Khan, and N. J. Ashill, "Drivers of user loyalty intention and commitment to a search engine: An exploratory study," J. Retail. Consum. Serv., vol. 44, no. June, pp. 71-81, 2018, doi: 10.1016/j.jretconser.2018.06.002.

[57] M. Thelwall, "Quantitative comparisons of search engine results," J. Am. Soc. Inf. Sci. Technol., vol. 59, no. 11, pp. 1702-1710, 2008, doi: 10.1002/asi.20834.

[58] Y. Tsuruoka, J. Tsujii, and S. Ananiadou, "FACTA: A text search engine for finding associated biomedical concepts," Bioinformatics, vol. 24, no. 21, pp. 2559-2560, 2008, doi: 10.1093/bioinformatics/btn469.

[59] E. Goldman, "Search Engine Bias and the Demise of Search Engine Utopianism,” no. Sullivan 2003, pp. 121-133, 2008, doi: 10.1007/978-3-540-75829-7_8.

[60] K. W. T. Leung, W. Ng, and D. L. Lee, "Personalized concept-based clustering of search engine queries," IEEE Trans. Knowl. Data Eng., vol. 20, no. 11, pp. 1505-1518, 2008, doi: 10.1109/TKDE.2008.84.

[61] C. MacDonald and I. Ounis, "The influence of the document ranking in expert search," Inf. Process. Manag., vol. 47, no. 3, pp. 376-390, 2011, doi: 10.1016/j.ipm.2010.09.004.

[62] K. C. Lee and S. Lee, "Interpreting the web-mining results by cognitive map and association rule approach," Inf. Process. Manag., vol. 47, no. 4, pp. 482-490, 2011, doi: 10.1016/j.ipm.2010.11.005.

[63] V. Derhami, E. Khodadadian, M. Ghasemzadeh, and A. M. Zareh Bidoki, "Applying reinforcement learning for web pages ranking algorithms," Appl. Soft Comput. J., vol. 13, no. 4, pp. 1686-1692, 2013, doi: 10.1016/j.asoc.2012.12.023.

[64] A. Makkar and N. Kumar, "An efficient deep learning-based scheme for web spam detection in IoT environment," Futur. Gener. Comput. Syst., vol. 108, pp. 467-487, 2020, doi: 10.1016/j.future.2020.03.004

[65] J. M. García, M. Junghans, D. Ruiz, S. Agarwal, and A. Ruiz-Cortés, "Integrating semantic Web services ranking mechanisms using a common preference model," Knowledge-Based Syst., vol. 49, pp. 22-36, 2013, doi: 10.1016/j.knosys.2013.04.007.

[66] M. S. Faisal, A. Daud, A. U. Akram, R. A. Abbasi, N. R. Aljohani, and I. Mehmood, "Expert ranking techniques for online rated forums," Comput. Human Behav., vol. 100, no. December 2017, pp. 168176, 2019, doi: 10.1016/j.chb.2018.06.013.

[67] T. W. L. Page, S. Brin, R. Motavni, "The PageRank Citation Ranking: Bringing Order to the Web," Tech. Report, Stanford Digit. Libr. Technol., 1998, doi: 10.1109/IISWC.2012.6402911.

[68] W. Xing and A. Ghorbani, "Weighted PageRank algorithm," Proc. - Second Annu. Conf. Commun. Networks Serv. Res., pp. 305-314, 2004. 
[69] K. Fujimura, T. Inoue, and M. Sugisaki, "The EigenRumor Algorithm for Ranking Blogs," Proc. Second Annu. Work. Weblogging Ecosyst. Aggregation, Anal. Dyn. Chiba, Japan, pp. 59-74, 2005.

[70] and J. K. S. Chakrabarti, B. E. Dom, S. R. Kumar, P. Raghavan, S.Rajagopalan, A. Tomkins, D. Gibson, "Mining the Link Structure of the World Wide Web," Computer (Long. Beach. Calif)., vol. 12, no. 23, pp. 60-67, 1999, doi: 10.1300/j101v12n23_04.

[71] A. M. Zareh Bidoki and N. Yazdani, "DistanceRank: An intelligent ranking algorithm for web pages," Inf. Process. Manag., vol. 44, no. 2, pp. 877-892, 2008, doi: 10.1016/j.ipm.2007.06.004.

[72] ShenJie, ChenChen, Zhanghui, S. Rong-Shuang, ZhuYan, and HeKun, "Tag Rank: A new rank algorithm for webpage based on social web," Proc. Int. Conf. Comput. Sci. Inf. Technol. ICCSIT 2008, pp. 254-258, 2008, doi: 10.1109/ICCSIT.2008.45.

[73] P. S. Sharma, D. Yadav, and P. Garg, "A systematic review on page ranking algorithms," Int. J. Inf. Technol., vol. 12, no. 2, pp. 329-337, 2020, doi: 10.1007/s41870-020-00439-3.

[74] X. Xie, Y. Fu, H. Jin, Y. Zhao, and W. Cao, "A novel text mining approach for scholar information extraction from web content in Chinese," Futur. Gener. Comput. Syst., vol. 111, pp. 859-872, 2020, doi: 10.1016/j.future.2019.08.033.

[75] I. S. Ahmad, A. A. Bakar, and M. R. Yaakub, "Movie Revenue Prediction Based on Purchase Intention Mining Using YouTube Trailer Reviews," Inf. Process. Manag., vol. 57, no. 5, p. 102278, 2020, doi: 10.1016/j.ipm.2020.102278.

[76] Y. Zhang et al., "Extracting geographic features from the Internet: A geographic information mining framework," Knowledge-Based Syst., vol. 174, pp. 57-72, 2019, doi: 10.1016/j.knosys.2019.02.031.

[77] G. A. Wang, J. Jiao, A. S. Abrahams, W. Fan, and Z. Zhang, "ExpertRank: A topic-aware expert fi nding algorithm for online knowledge communities," Decis. Support Syst., vol. 54, no. 3, pp. 14421451, 2013, doi: 10.1016/j.dss.2012.12.020.

[78] B. Vasilescu, V. Filkov, U. C. Davis, and A. Serebrenik, "StackOverflow and GitHub : Associations Between Software Development and Crowdsourced Knowledge," 2013, doi: 10.1109/SocialCom.2013.35.

[79] L. Zhe and B. J. Jansen, "Questioner or question: Predicting the response rate in social question and answering on Sina Weibo," vol. 54, no. September 2017, pp. 159-174, 2018, doi: 10.1016/j.ipm.2017.10.004.

[80] D. Madrid, I. Cantador, A. Bellogín, M. E. Cortés-cediel, and O. Gil, "Personalized recommendations in e-participation: Offline experiments for the Personalized recommendations in e-participation: Offline experiments for the 'Decide Madrid ' platform," no. August, 2017, doi: 10.1145/3127325.3127330.

[81] Z. Zhao, L. Zhang, X. He, and W. Ng, "Expert Finding for Question Answering via Graph Regularized Matrix Completion," vol. 4347, no. c, pp. 1-12, 2014, doi: 10.1109/TKDE.2014.2356461.

[82] R. N. Srivastava, Divya., and Mall, "Structural Analysis of L-Bracket using ANSYS," i-manager's J. Mech. Eng., vol. 7, no. 2, 2017, doi: https://doi.org/10.26634/jme.7.2.13432.

[83] H. Kareem and L. Asker, "Detecting Hierarchical Ties Using Link-Analysis Ranking at Different Levels of Time Granularity," pp. 1-4.

[84] J. Zhang, M. S. Ackerman, and K. K. Nam, "QuME : A Mechanism to Support Expertise Finding In Online Help-seeking Communities," in Proceedings of the 20th annual ACM symposium on User interface software and tech-nology, 2007, pp. 111-114.

[85] G. Matošević, J. Dobša, and D. Mladenić, "Using machine learning for web page classification in search engine optimization," Futur. Internet, vol. 13, no. 1, pp. 1-20, 2021, doi: 10.3390/fi13010009.

[86] I. C. Drivas, D. P. Sakas, G. A. Giannakopoulos, and D. Kyriaki-Manessi, "Big data analytics for search engine optimization," Big Data Cogn. Comput., vol. 4, no. 2, pp. 1-22, 2020, doi: 10.3390/bdcc4020005.

[87] S. Wu, Q. Shen, Y. Deng, and J. Cheng, "Natural-language-based intelligent retrieval engine for BIM object database," Comput. Ind., vol. 108, pp. 73-88, 2019, doi: 10.1016/j.compind.2019.02.016.

[88] R. S. Rao and A. R. Pais, "Jail-Phish: An improved search engine based phishing detection system," Comput. Secur., vol. 83, pp. 246-267, 2019, doi: 10.1016/j.cose.2019.02.011.

[89] S. Sun, Y. Wei, K. L. Tsui, and S. Wang, "Forecasting tourist arrivals with machine learning and internet search index," Tour. Manag., vol. 70, no. July 2018, pp. 1-10, 2019, doi: 10.1016/j.tourman.2018.07.010.

[90] M. Bonart, A. Samokhina, G. Heisenberg, and P. Schaer, "An investigation of biases in web search engine query suggestions," Online Inf. Rev., vol. 44, no. 2, pp. 365-381, 2020, doi: 10.1108/OIR-112018-0341.

[91] A. Sayed and A. Al Muqrishi, "IBRI-CASONTO: Ontology-based semantic search engine," Egypt. Informatics J., vol. 18, no. 3, pp. 181-192, 2017, doi: 10.1016/j.eij.2017.01.001.

[92] A. D. Hesham Abdo Ahmed Aqlan, Shoiab Ahmed, "Death Prediction and Analysis Using Web Mining Techniques," 2017. 
[93] P. Sharma, S. A.K, and P. Garg, "Design of a Framework for Knowledge Based Web Page Ranking," Int. J. Eng. Technol., vol. 9, no. 3, pp. 2236-2244, 2017, doi: 10.21817/ijet/2017/v9i3/1709030219.

[94] I. B. Vidinli and R. Ozcan, "New query suggestion framework and algorithms: A case study for an educational search engine," Inf. Process. Manag., vol. 52, no. 5, pp. 733-752, 2016, doi: 10.1016/j.ipm.2016.02.001.

[95] C. Mao, J. Chen, D. Towey, J. Chen, and X. Xie, "Search-based QoS ranking prediction for web services in cloud environments," Futur. Gener. Comput. Syst., vol. 50, pp. 111-126, 2015, doi: 10.1016/j.future.2015.01.008.

[96] J. Lee, J. K. Min, A. Oh, and C. W. Chung, "Effective ranking and search techniques for Web resources considering semantic relationships," Inf. Process. Manag., vol. 50, no. 1, pp. 132-155, 2014, doi: 10.1016/j.ipm.2013.08.007.

[97] Y. A. Kim and G. W. Park, "Topic-Driven SocialRank: Personalized search result ranking by identifying similar, credible users in a social network," Knowledge-Based Syst., vol. 54, pp. 230-242, 2013, doi: 10.1016/j.knosys.2013.09.011.

[98] S. Garcia Esparza, M. P. O’Mahony, and B. Smyth, "Mining the real-time web: A novel approach to product recommendation," Knowledge-Based Syst., vol. 29, pp. 3-11, 2012, doi: 10.1016/j.knosys.2011.07.007.

[99] M. Schedl, G. Widmer, P. Knees, and T. Pohle, "A music information system automatically generated via Web content mining techniques," Inf. Process. Manag., vol. 47, no. 3, pp. 426-439, 2011, doi: 10.1016/j.ipm.2010.09.002.

[100] H. Wang, C. C. Tan, and Q. Li, "Snoogle: A search engine for pervasive environments," IEEE Trans. Parallel Distrib. Syst., vol. 21, no. 8, pp. 1188-1202, 2010, doi: 10.1109/TPDS.2009.145. 